\title{
Assessment of projected changes in upland environments using simple climatic indices
}

\author{
J. M. Clark ${ }^{1,2,7, *}$, H. G. Orr ${ }^{3}$, J. Freer ${ }^{4}$, J. I. House ${ }^{5}$, P. Smith ${ }^{6}$, C. Freeman ${ }^{1}$ \\ ${ }^{1}$ Wolfson Carbon Capture Laboratory, School of Biological Sciences, Bangor University, Deiniol Road, Bangor, \\ Gwynedd LL57 2UW, UK \\ ${ }^{2}$ Grantham Institute for Climate Change Fellow, Civil and Environmental Engineering, Imperial College London, \\ Skempton Building, South Kensington, London SW7 2AZ, UK \\ ${ }^{3}$ Research and Innovation (Climate Change), Environment Agency, Environment Centre Wales, Deiniol Road, \\ Bangor LL57 2UW, UK \\ ${ }^{4}$ School of Geographical Sciences, University of Bristol, Queens Road, Bristol BS8 1RJ, UK
}

${ }^{5}$ QUEST, Department of Earth Sciences, University of Bristol, Wills Memorial Building, Queens Road, Bristol BS8 1RJ, UK

${ }^{6}$ Institute of Biological and Environmental Sciences, School of Biological Sciences, Aberdeen University, 23 St Machar Drive, Aberdeen AB24 3UU, UK

${ }^{7}$ Present address: Walker Institute for Climate Systems Research and Soils Research Centre, Department of Geography and Environmental Science, School of Human and Environmental Sciences, University of Reading, Whiteknights, PO Box 233, Reading RG6 6DW, UK

\begin{abstract}
Climate controls upland habitats, soils and their associated ecosystem services; therefore, understanding possible changes in upland climatic conditions can provide a rapid assessment of climatic vulnerability over the next century. We used 3 different climatic indices that were optimised to fit the upland area classified by the EU as a Severely Disadvantaged Area (SDA) 1961-1990. Upland areas within the SDA covered all altitudinal ranges, whereas the maximum altitude of lowland areas outside of the SDA was ca. $300 \mathrm{~m}$. In general, the climatic index based on the ratio between annual accumulated temperature (as a measure of growing season length) and annual precipitation predicted $96 \%$ of the SDA mapped area, which was slightly better than those indices based on annual or seasonal water deficit. Overall, all climatic indices showed that upland environments were exposed to some degree of change by 2071-2100 under UKCIP02 climate projections for high and low emissions scenarios. The projected area declined by 13 to $51 \%$ across 3 indices for the low emissions scenario and by 24 to $84 \%$ for the high emissions scenario. Mean altitude of the upland area increased by +11 to $+86 \mathrm{~m}$ for the low scenario and +21 to $+178 \mathrm{~m}$ for the high scenario. Low altitude areas in eastern and southern Great Britain were most vulnerable to change. These projected climatic changes are likely to affect upland habitat composition, long-term soil carbon storage and wider ecosystem service provision, although it is not yet possible to determine the rate at which this might occur.
\end{abstract}

KEY WORDS: Uplands $\cdot$ Altitude $\cdot$ Great Britain $\cdot$ Climate change $\cdot$ Climatic index

\section{INTRODUCTION}

The British uplands contain most of the national soil carbon stocks, supply $\sim 70 \%$ of the drinking water, are used to supply food and timber, and support tourism and many recreational activities (Orr et al. 2008). They are characterised by a cool and wet climate that supports a globally rare range of bog, heathland and grassland habitats that have developed on podzolic soils and blanket peats (Ratcliffe \& Thompson 1988). Vegetation change across upland areas closely follows altitudinal and oceanic (i.e. west-east) gradients in temperature, precipitation, cloud cover and wind speed (Grace \& Unsworth 1988, Ratcliffe \& Thompson 1988). As climate plays a crucial role in shaping these environments, the uplands and their ecosystem ser- 
vices are thought to be particularly sensitive to climate change (Holden et al. 2007, Orr et al. 2008).

Future climate change projections of warmer and potentially drier conditions could have a wide range of impacts on upland environments, affecting ecosystem services such as biodiversity (Berry et al. 2003), soil carbon storage (Worrall et al. 2009), water supply and water quality (Fowler et al. 2003, Malby et al. 2007, Whitehead et al. 2009). Although the potential risks associated with climate change have been widely discussed, the actual spatial extent and time scale over which projected changes in climate could impact and begin to alter the uplands and their ecosystem services have not been presented in detail for Great Britain (GB). Given the dependence of upland ecosystems on climatic conditions and the immediate need for easily accessible climatic vulnerability assessments to inform policy, we explore the potential for simple climatic indices to characterise and assess potential changes in upland environments at a national level.

The uplands are thought to cover around one-third of GB (Ratcliffe \& Thompson 1988). However, the area of GB covered by different upland classification system ranges from 16.7 to $42.1 \%$ of the country (Table 1 , Fig. 1). Intuitively, upland areas are assumed to be high-altitude areas, in contrast to low-altitude lowlands. The close relationship between altitude, climate and vegetation means that upland areas have often been defined as land $>300 \mathrm{~m}$ above sea level (Atherden 1992). In practice, the habitats and soils associated with upland environments in high-altitude areas are also found at low altitudes, and even at sea level in the

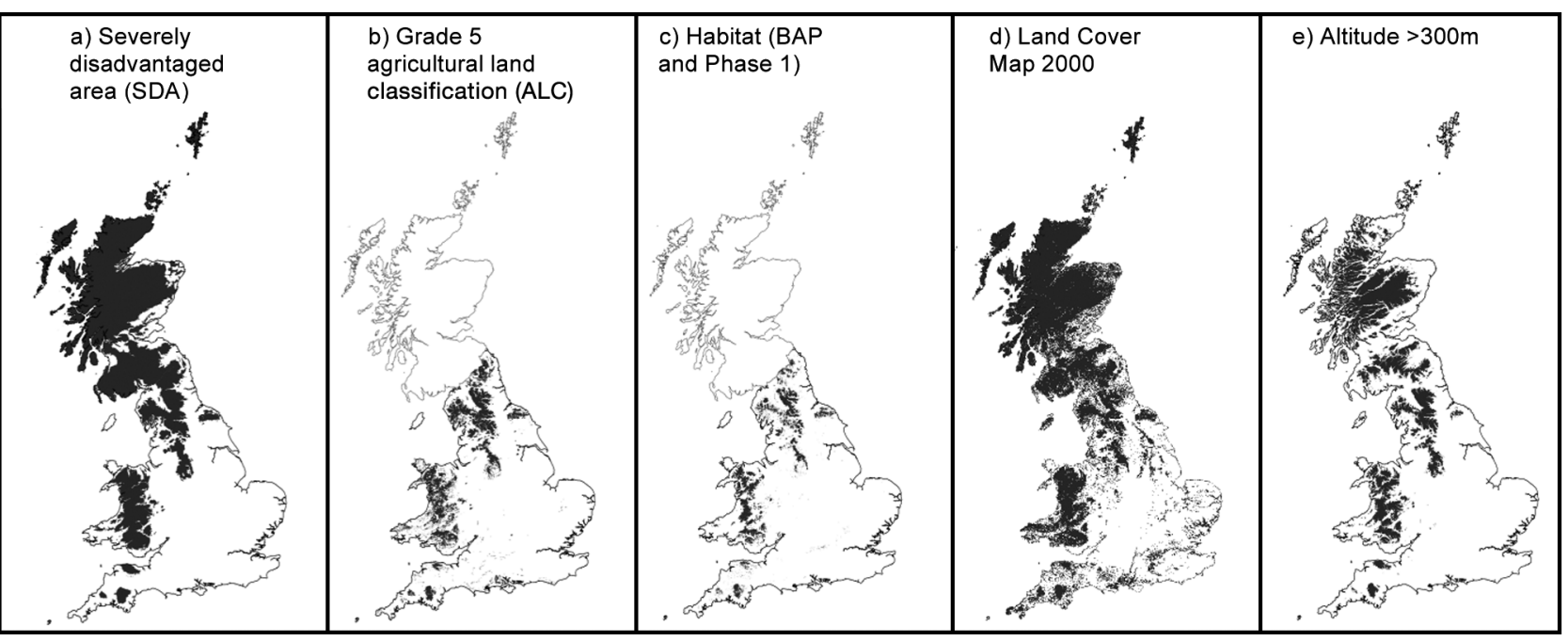

Fig. 1. Upland areas in Great Britain based on 5 different classifications. Data sources are shown in Table 2. (a,b) Data for England (C)rown Copyright. All rights reserved 2010. Data for Wales were provided by The Welsh Assembly Government, Department of Rural Affairs, and data for Scotland were reproduced under the terms of the Click-Use Licence. (c) Upland habitat was defined as upland blanket bog, heathland, grassland, woodland and mountain habitat, as derived from the Biodiversity Action Plan (England) and Phase 1 Habitat Map (Wales). Data for England @Natural England copyright 2010. Data for Wales @C Crown copyright. All rights reserved. Countryside Council for Wales, 100018813 2010. (d) 25 m resolution Centre for Ecology and Hydrology (CEH) Landcover 2000 map for the following land cover types (with their classification numbers): acid grass (8.1), dwarf shrub heath (10.1), open shrub heath (10.2), bog (12.1) and montane habitats (15.1); ONERC (CEH) 2002. (e) OCrown Copyright/database right 2010. An Ordnance Survey/EDINA supplied service. BAP: biodiversity action plan

Table 1. Areas defined as upland in Great Britain using the 5 classifications shown in Fig. 1. See Fig. 1 legend for more data details. BAP: biodiversity action plan

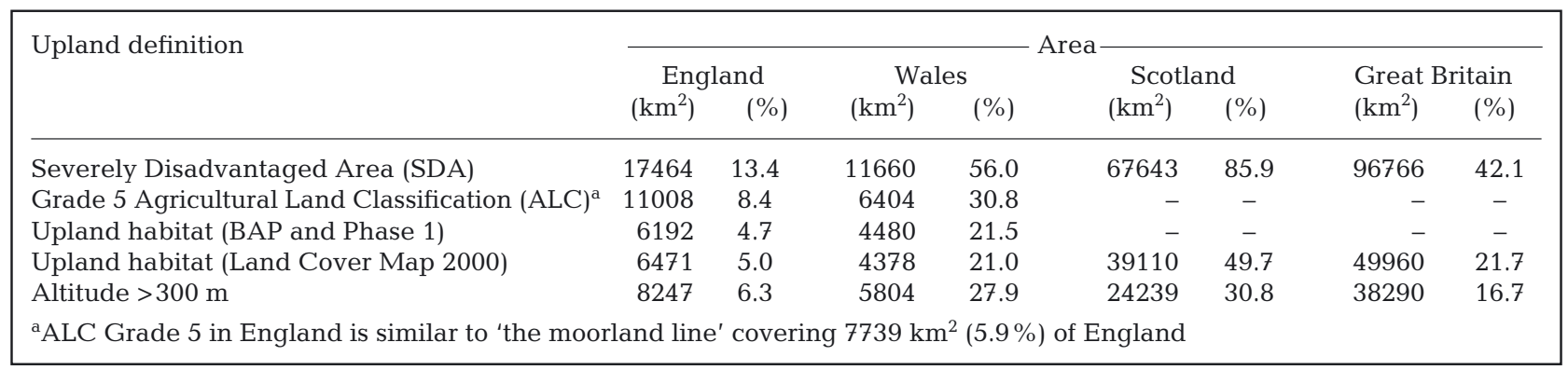


far north of Scotland (Fielding \& Haworth 1999). Given the dominance of dwarf-shrub heaths, rough grassland and blanket bog habitats in the uplands (Thompson \& Brown 1992, Averis et al. 2004), upland areas can also be defined and mapped based on ecological characteristics such as habitat or land cover. However, agricultural improvement and abandonment over time renders vegetation and habitat an unreliable indicator of the current environmental conditions. Culturally, uplands are defined as areas of extensive agriculture beyond the limit of enclosed cultivation (Ratcliffe 1977), which is, in part, a reflection of the harsh climate, limited potential of these soils for agriculture and unfavourable topography in many locations. As such, the uplands are comparatively economically deprived, and were classified by the European Union in 1975 as Severely Disadvantaged Areas (SDAs) or Grade 5 agricultural land in England and Wales. However, this socioeconomic upland classification is particular to GB and not the EU as a whole, as the cool and wet upland environment associated with the British SDA is not the same as the warm and dry environment associated with SDA regions in Spain, for instance.

As climate fundamentally determines plant growth and longer-term soil formation in upland environments (Fielding \& Haworth 1999, Averis et al. 2004), a robust definition of upland areas can be based on climatic data that characterise the upland environment. Climatic indices based on temperature, precipitation and potential evapotranspiration have been used to map bioclimatic zones globally (Koppen 1900, Thornthwaite 1948, Bagnouls \& Gaussen 1957, Holdridge 1959, Mather 1974) and many are still widely used today (Feddema 2005, Peel et al. 2007). For the British uplands, Averis et al. (2004) demonstrated that an index of climate severity (CS), based on the ratio between the total number of raindays and annual accumulated temperature (Gregory 1954), was able to delineate upland areas above a specified threshold.

The utility of any climatic index in assessing possible future changes in the upland environment is partly dependent on the reliability of the climate projections for each of the climate variables used. Climate indices based on some of the most uncertain and least available climate variables (e.g. wind speed and raindays) may be less useful for long-term studies than indices based on more readily available climate data (e.g. temperature). For instance, problems have been encountered with future calculations of potential evaporation, as the uncertainty in some of the data required by some more physically based models can result in unreliable future estimates (Kay \& Davies 2008). In the case of the CS index, data on raindays were not readily available, and generation of such data using a weather generator (Kilsby et al. 2007) adds further complicating factors associated with validating a more complex and time-consuming approach. This compromises the apparent advantages of using simple indices to provide a rapid 'first-cut' assessment of the potential climatic vulnerability that is needed to help inform management and policy decisions. Therefore, we examined a range of potential climatic indices with simple and/or more physically meaningful relationships for upland environments.

In this study, we present an assessment of recent and projected future changes in upland environments by examining change in simple climatic indices using the Met Office/UK Climate Impacts Programme (UKCIP) gridded climate data (Perry \& Hollis 2005) and UKCIP02 climate projections for high and low emissions scenarios (Hulme et al. 2002). To ensure that climatic indices were based on readily available robust climatic data, we modified the original CS index (Averis et al. 2004) based on raindays and compared this to new indices based on other physically meaningful climate variables. These additional climate variables included the annual and seasonal balance between precipitation and potential evaporation, which can capture wet and cold climatic conditions. Our aims were to determine: (1) the best climatic indices and/or variables that define upland environments in GB and (2) whether recent and projected future changes in climate affect the spatial extent and altitudinal range of upland environments. Given the simplicity of the approach, we incorporated measures of uncertainty in the climate data to provide a plausible range for each index under current and future climate projections. This approach was consistent with a tier 2 assessment under the UKCIP risk-uncertainty framework (Willows \& Connell 2003), as it provides a quantitative regional assessment to enable vulnerable and/or priority areas to be identified. Although there are limitations with simple climate indices that, combined with uncertainty in GCM projections, make future projections highly uncertain, previous research on acid rain in the 1980s has shown that uncertain models can produce indicative information that is useful for policy (Whitehead et al. 2009).

\section{METHODS}

\subsection{Data sets}

Spatial data used to define upland areas under different classification systems are listed in Table 2 . The SDA was selected as the working definition of upland areas for the present study as it provided the most comprehensive and inclusive cover of the uplands across GB. The SDA map for England, Wales and Scotland was converted to a $5 \mathrm{~km}$ grid to match the resolution of 
Table 2. Data sets used in the present study

\begin{tabular}{|ll|}
\hline Data set & Source/URL \\
\hline $\begin{array}{l}\text { Severely Disadvantaged Areas (SDAs): } \\
\text { England }\end{array}$ & Defra (via www.magic.gov.uk) \\
$\begin{array}{l}\text { Wales } \\
\text { Scotland }\end{array}$ & $\begin{array}{l}\text { The Welsh Assembly Government, Department of Rural Affairs (wales.gov.uk) } \\
\text { Scottish Government (www.scotland.gov.uk) }\end{array}$ \\
$\begin{array}{l}\text { Agricultural Land Classification (ALC): } \\
\text { England }\end{array}$ & Defra (via www.magic.gov.uk) \\
$\begin{array}{l}\text { Wales } \\
\text { Biodiversity Action Plan (BAP) habitat } \\
\text { maps for England }\end{array}$ & The Welsh Assembly Government, Department of Rural Affairs (wales.gov.uk) \\
$\begin{array}{l}\text { Phase } 1 \text { habitat survey for Wales } \\
\text { Land Cover Map 2000 (LCM2000) }\end{array}$ & Countryside Council for Wales (www.ccw.gov.uk) \\
$\begin{array}{l}\text { Ordnance Survey } 50 \text { m digital elevation } \\
\text { model and country boundary data }\end{array}$ & Centre for Ecology and Hydrology (www.ceh.ac.uk) \\
Monthly 5 km gridded climate data 1921-2005 & EDINA/Digimap (edina.ac.uk/digimap) \\
UKCIP02 climate projections & Met Office/UKCIP (www.metoffice.gov.uk) \\
\hline
\end{tabular}

Table 3. Gridded monthly climate variables from observations (Perry \& Hollis 2005) and future climate projections (Hulme et al. 2002), provided by UKCIP/Met Office. The $50 \mathrm{~km}$ scenario data were provided as either difference or factorial change between the mean modelled baseline (1961-1990) and future monthly climate mean. The 2020s are the mean climate for 2011-2040, the 2050s are the mean climate for 2041-2070 and the 2080s are the mean climate for 2071-2100

\begin{tabular}{|c|c|c|c|c|c|}
\hline \multirow[t]{2}{*}{ Variable } & \multicolumn{2}{|c|}{ Observed data $(5 \mathrm{~km})$} & \multirow{2}{*}{ Units } & \multicolumn{2}{|c|}{ Future data (UKCIP02) $(50 \mathrm{~km})$} \\
\hline & Units & Time period & & $\begin{array}{c}\text { Difference/ } \\
\text { Factor }\end{array}$ & Time period \\
\hline Daily maximum temperature & ${ }^{\circ} \mathrm{C}$ & $1914-2005$ & ${ }^{\circ} \mathrm{C}$ & Difference & 2020 s, 2050s, 2080s \\
\hline Daily minimum temperature & ${ }^{\circ} \mathrm{C}$ & $1914-2005$ & ${ }^{\circ} \mathrm{C}$ & Difference & $2020 \mathrm{~s}, 2050 \mathrm{~s}, 2080 \mathrm{~s}$ \\
\hline Total precipitation & $\mathrm{mm} \mathrm{mo} \mathrm{m}^{-1}$ & $1914-2005$ & $\%$ & Factor & $2020 \mathrm{~s}, 2050 \mathrm{~s}, 2080 \mathrm{~s}$ \\
\hline Sunshine duration & $\mathrm{h} \mathrm{mo}^{-1}$ & $1929-2005$ & - & - & - \\
\hline Mean cloud cover & $\%$ & 1961-2005 & $\%$ & Factor & $2020 \mathrm{~s}, 2050 \mathrm{~s}, 2080 \mathrm{~s}$ \\
\hline Days of rain $>1 \mathrm{~mm}$ & no. days & 1961-2005 & - & - & - \\
\hline
\end{tabular}

the climate data used. Grid squares were classified as upland where SDA was $>50 \%$ of the area. As a result, small areas (Scilly Isles, Lundy Island, Quantock Hills, western Llyn Peninsula) and those at the edge of the SDA were not included.

The climate variables used in the present study are summarised in Table 3. Climate data from 1961-1990 were used as the baseline period to be consistent with UKCIP02 projections. Data from 1921-1950, 19311960, 1941-1970, 1951-1980 and 1971-2000 were used to examine recent climate change.

Future climate projections were taken from UKCIP (Hulme et al. 2002) (summarised in Table 3). We used the UKCIP02 low and high emissions scenarios that correspond to the IPCC SRES B1 and A1F1 emission scenarios (Nakicenovic et al. 2000), resulting in a mean change in mean annual temperature change of +2 and $+3.5^{\circ} \mathrm{C}$ by 2100 , respectively (Hulme et al. 2002). The UKCIP02 climate change scenarios were generated from the Hadley Centre Climate Model (HadCM3). More recent probabilistic UKCP09 projections were not available at the time the work was carried out. However, both UKCIP02 and UKCP09 scenarios are based on runs from the same climate model (HadCM3) using similar emissions scenarios. Recent analysis of UKCP09 projections compared to previous ensembles of climate projections from UKCIP02, carried out for the ENSEMBLES and PRUDENCE projects (Hewitt \& Griggs 2004, Christensen et al. 2007), show that there is almost no change in the distribution of the most important projected climatic variables used in this study. Specific differences between UKCIP02 and UKCP09 projections are discussed further in Clark et al. (2010, this Special).

\subsection{Climate indices}

Global climate indices have been constructed based on simple relationships between temperature and precipitation (Bagnouls \& Gaussen 1957), and measures of the water deficit and surplus estimated from precipita- 
tion and potential evaporation (Thornthwaite \& Mather 1955, Holdridge 1959). More recent global bioclimatic classifications have included a combination of temperature, accumulated temperature and a drought index based on seasonal precipitation and soil water deficit (Prentice et al. 1992). For the British uplands, characterised by cool and wet climates, we (1) applied and modified the Averis et al. (2004) CS index, and compared the output to (2) the widely used ThornthwaiteMather index (Thornthwaite \& Mather 1955, Willmott \& Feddema 1992) and (3) our own index based on the seasonal balance between precipitation and evaporation, as seasonality in precipitation and water deficit has been noted to be a key variable (Prentice et al. 1992, Peel et al. 2007).

(1) The original and modified climate severity (CS) index (Averis et al. 2004) are as follows:

$$
\mathrm{CS}=\frac{\sum_{m=1}^{12} \mathrm{RD}_{m}}{\sum_{m=1}^{12} d_{m} T_{m}}
$$

where $\mathrm{RD}_{m}$ is the number of days in a month with rainfall $>1 \mathrm{~mm}, \Sigma d_{m} T_{m}$ is the annual accumulated temperature (Gregory 1954), $d_{m}$ is the number of days in a month, $T_{m}$ is the mean monthly temperature $\left({ }^{\circ} \mathrm{C}\right)$ and $m$ is the month.

Modifications to the CS index were explored to find a more readily available proxy variable to replace raindays (see Table 6). A significant positive linear relationship was found between raindays and the log of total annual precipitation $\left(P, \mathrm{~mm} \mathrm{yr^{-1 }}\right)\left(\mathrm{R}^{2}=0.62\right.$, $\mathrm{p}<0.0001)$, allowed the following modification $\left(\mathrm{MCS}_{\mathrm{r}}\right)$ :

$$
\operatorname{MCS}_{\mathrm{r}}=\frac{\ln (P)}{\sum_{m=1}^{12} d_{m} T_{m}}
$$

However, it should be noted that there was considerable scatter in the data, and so replacement of raindays with the log of total annual precipitation was not a straight substitution. A significant but quite poor negative linear relationship was also found between raindays and the total annual number of sunshine hours $\left(\mathrm{R}^{2}=0.52, \mathrm{p}<0.0001\right)$, allowing a second modification $\left(\mathrm{MCS}_{\mathrm{S}}\right)$ :

$$
\mathrm{MCS}_{\mathrm{S}}=\frac{\sum_{m=1}^{12} d_{m} S_{m}}{\sum_{m=1}^{12} d_{m} T_{m}}
$$

where $S_{m}$ is the average number of bright sunshine hours in month $m$. Substitution of total annual precipitation for raindays assumes that the number of raindays represents a wet climate only. In contrast, substitution of sunshine hours for raindays could imply that raindays is also a proxy measure of cloudiness, which in turn would control the amount of photosynthetically active radiation available for plant growth.

(2) The annual balance between total precipitation $(P)$ and potential evaporation (PE), as measured by the modified Thornthwaite-Mather Moisture index (TMI) (Thornthwaite \& Mather 1955, Willmott \& Feddema 1992), was calculated as follows:

$$
\mathrm{TMI}=\left\{\begin{array}{l}
P / \mathrm{PE}-1, P<\mathrm{PE} \\
1-\mathrm{PE} / P, P \geq \mathrm{PE}
\end{array}\right.
$$

where $\mathrm{PE}$ is the annual potential evaporation $(\mathrm{mm})$ calculated as the sum of monthly PE estimated using mean monthly temperature (see below, this section).

(3) The seasonal balance between precipitation and potential evaporation was calculated by the annual accumulated monthly water deficit (AAMWD), as follows:

AAMWD $=\sum_{m=1}^{12}$ MWD where MWD $= \begin{cases}P_{m}-\mathrm{PE}_{m} & {\left[P_{m}<\mathrm{PE}_{m}\right]} \\ 0 & {\left[P_{m}>\mathrm{PE}_{m}\right]}\end{cases}$

where MWD is the monthly water deficit for month $m$, $P_{m}$ is monthly precipitation $\left(\mathrm{mm} \mathrm{mo}^{-1}\right)$ and $\mathrm{PE}_{m}$ is monthly potential evaporation $\left(\mathrm{mm} \mathrm{mo}^{-1}\right)$.

$\mathrm{PE}_{m}$ was estimated in all cases using the modified Thornthwaite equation (Thornthwaite 1948, Mather 1978):

$$
\mathrm{PE}_{m}=16\left(\frac{N_{\mathrm{d}}}{12}\right)\left(\frac{10 T_{a}}{\mathrm{HI}}\right)^{m}
$$

where $T_{a}$ is the mean monthly air temperature $\left({ }^{\circ} \mathrm{C}\right)$, defined here as the mean of daily maximum and minimum temperature (Allen et al. 1998). $\mathrm{PE}_{m}$ was taken to be zero when $T_{a}<0^{\circ} \mathrm{C}$. HI is the annual heat index, $m$ is a parameter based on $\mathrm{HI}$ and $N_{\mathrm{d}}$ is the mean number of daylight hours (Allen et al. 1998):

$$
\mathrm{HI}=\sum_{i=1}^{12}\left(\frac{T_{a i}}{5}\right)^{1.514}
$$

$m=6.7 \times 10^{-7}[\mathrm{HI}]^{3}-7.7 \times 10^{-5}[\mathrm{HI}]^{2}+1.8 \times 10^{-2}[\mathrm{HI}]+0.49$

$N_{\mathrm{d}}=\frac{24}{\pi}\left(\arccos \left\{-\tan (L) \tan \left(0.409 \sin \left[\frac{2 \pi}{365} J-1.39\right]\right)\right\}\right)$

where $L$ is the latitude in radians and $J$ is the day of the year. The modified Thornthwaite equation was used to provide an estimate of potential evaporation based on minimal data requirements and simple climatic variables. In general, it has been argued that this equation provides a reasonable estimate of monthly PE where there are no marked changes in seasonal humidity (e.g. monsoon climate) (Mather 1978). 


\subsection{Data analysis}

Climate data analysed included directly measured climatic variables, such as precipitation, and derived climatic variables, such as the number of consecutive dry days (Table 4). Relationships between these climatic variables were explored initially using nonparametric Spearman's rank correlation to provide a fuller understanding of the relationship between climatic variables used in the climate indices and other climate variables that were not used.

Each climatic index was calculated for the 19611990 baseline period using the following method. For each observed climate variable (e.g. precipitation,

Table 4. Summary climate statistics 1961-1990 for upland areas that fall within the Severely Disadvantaged Area (SDA) (Fig. 1) and lowland areas of Great Britain that are outside the SDA. Met Office/UKCIP $5 \mathrm{~km}$ gridded climate data and Ordnance Survey/EDINA digital elevation model data aggregated to $5 \mathrm{~km}$ were used. Annual minimum-maximum values are shown, with mean values in brackets

\begin{tabular}{|c|c|c|c|}
\hline \multirow{2}{*}{ Variable } & \multirow[t]{2}{*}{ Unit } & \multicolumn{2}{|c|}{$\ldots$ Value } \\
\hline & & Upland & Lowland \\
\hline Altitude & $\mathrm{m}$ & $\begin{array}{c}5-948 \\
(278)\end{array}$ & $\begin{array}{c}0-288 \\
(73)\end{array}$ \\
\hline $\begin{array}{l}\text { Total annual } \\
\text { precipitation }\end{array}$ & $\mathrm{mm} \mathrm{yr}^{-1}$ & $\begin{array}{c}633-4134 \\
(1455)\end{array}$ & $\begin{array}{l}507-3325 \\
\quad(798)\end{array}$ \\
\hline Rainfall intensity & $\mathrm{mm} \mathrm{d}^{-1}$ & $\begin{array}{l}4.4-14.4 \\
(7.8)\end{array}$ & $\begin{array}{c}4.0-11.3 \\
(5.8)\end{array}$ \\
\hline Days of rain $>1 \mathrm{~mm}^{\mathrm{a}}$ & d & $\begin{array}{l}125-266 \\
(185)\end{array}$ & $\begin{array}{l}102-243 \\
(132)\end{array}$ \\
\hline $\begin{array}{l}\text { Max. number of conse- } \\
\text { cutive dry days }{ }^{\mathrm{b}}\end{array}$ & d & $\begin{array}{l}5-19 \\
(13)\end{array}$ & $\begin{array}{c}9-22 \\
(17)\end{array}$ \\
\hline $\begin{array}{l}\text { Mean daily minimum } \\
\text { temperature }\end{array}$ & ${ }^{\circ} \mathrm{C}$ & $\begin{array}{c}0.0-7.0 \\
(3.8)\end{array}$ & $\begin{array}{c}3.4-9.3 \\
(5.6)\end{array}$ \\
\hline $\begin{array}{l}\text { Mean daily maximum } \\
\text { temperature }\end{array}$ & ${ }^{\circ} \mathrm{C}$ & $\begin{array}{l}3.4-14.1 \\
(10.3)\end{array}$ & $\begin{array}{l}8.5-14.5 \\
(12.8)\end{array}$ \\
\hline Mean annual temperature & ${ }^{\circ} \mathrm{C}$ & $\begin{array}{l}1.7-10.3 \\
(7.1)\end{array}$ & $\begin{array}{l}6.9-11.5 \\
(9.2)\end{array}$ \\
\hline Growing degree days $^{c}$ & GDD & $\begin{array}{l}148-1887 \\
(1074)\end{array}$ & $\begin{array}{l}855-2155 \\
(1642)\end{array}$ \\
\hline $\begin{array}{l}\text { Annual accumulated } \\
\text { temperature }\end{array}$ & ${ }^{\circ} \mathrm{C}$ & $\begin{array}{l}616-3759 \\
(2588)\end{array}$ & $\begin{array}{l}2526-4220 \\
(3372)\end{array}$ \\
\hline Growing season length ${ }^{\mathrm{d}}$ & d & $\begin{array}{c}90-333 \\
(242)\end{array}$ & $\begin{array}{l}227-361 \\
(296)\end{array}$ \\
\hline Sunshine duration & $\mathrm{h} \mathrm{d}^{-1}$ & $\begin{array}{c}1.9-4.3 \\
(3.2)\end{array}$ & $\begin{array}{c}2.8-5.2 \\
(3.9)\end{array}$ \\
\hline Cloud cover & $\%$ & $\begin{array}{l}68.8-78.3 \\
(72.8)\end{array}$ & $\begin{array}{c}64.9-76.9 \\
(69.9)\end{array}$ \\
\hline \multicolumn{4}{|c|}{$\begin{array}{l}\text { a Number of days in a year where rainfall is } \geq 1 \mathrm{~mm} \text { in } 24 \mathrm{~h} \\
\text { period between 09:00 and 09:00 } \mathrm{h}\end{array}$} \\
\hline \multirow{2}{*}{\multicolumn{4}{|c|}{$\begin{array}{l}{ }^{\mathrm{b}} \text { Longest spell of consecutive days with total precipitation } \\
\leq 0.2 \mathrm{~mm} \mathrm{~d} \mathrm{~d}^{-1} \\
\mathrm{c} \Sigma(\text { daily mean temperature }-5.5) \text { whenever daily mean } \\
\text { temperature }>5.5^{\circ} \mathrm{C}\end{array}$}} \\
\hline & & & \\
\hline \multicolumn{4}{|c|}{$\begin{array}{l}\text { d Period bounded by daily mean temperature }>5^{\circ} \mathrm{C} \text { for }>5 \\
\text { consecutive days and daily mean temperature }<5^{\circ} \mathrm{C} \text { for } \\
>5 \text { consecutive days (after } 1 \text { July) }\end{array}$} \\
\hline
\end{tabular}

mean temperature, etc.) used in the analysis, the mean $[E(X)]$ and $95 \%$ confidence intervals for the mean value for each month over the $30 \mathrm{yr}$ period were calculated:

$\left(E(X)^{-}, E(X)^{+}\right)=\left(E(X)-t_{0.95} \sqrt{\frac{V(X)}{\mathrm{N}}}, E(X)+t_{0.95} \sqrt{\frac{V(X)}{\mathrm{N}}}\right)$

where $t_{0.95}$ is the critical value from the Student's $t$ distribution for $(\mathrm{N}-1)$ degrees of freedom [ $t(29)$ in this case], $V(X)$ is the variance and $\mathrm{N}$ is the number of years. Each climatic index $\left(C S, \mathrm{MCS}_{\mathrm{r}}, \mathrm{MCS}_{\mathrm{S}}, \mathrm{TMI}\right.$ and AAMWD) was then calculated using the mean climate data only. These data were used to define the upland threshold (discussed below, this section). Combinations of the upper and/or lower $95 \%$ confidence intervals of the mean value for each climate variable were then used to determine an upper and lower limit for the range of areas covered by the upland threshold for each climatic index.

Although there is considerable variation in each climatic variable between years, climate refers to the long-term average of these variables as well as their extremes and likelihood of occurrence over a period of time (Mather 1974). UKCIP uses the standard $30 \mathrm{yr}$ period to present average values for the baseline climate and future projections (Hulme et al. 2002). By using the confidence intervals for the mean value of each climate variable, we were able to incorporate a measure of uncertainty of the standard method of reporting average climatic variables. Such quantification of the uncertainty of rarely achieved in similar studies and we see this as a necessary step in understanding the likely impacts of change. Our handling of the uncertainty was a pragmatic solution given the quality and quantity of the data sets used and that we applied this assessment at the national scale. We recognise that this approach is an approximation of the error distribution of the data.

Climatic index values calculated using the mean 1961-1990 climate data were used to define the upland threshold that most closely fitted the SDA map. Threshold values were chosen so that the area defined as upland covered the largest possible area of the SDA $\left(\mathrm{SDA}_{\mathrm{T}}\right)$, minimum possible area outside the SDA (noS$\mathrm{DA}_{\mathrm{T}}$ ) and minimum possible area within the SDA not covered by the threshold value (SDAnoT). Essentially, this involved solving the following equation to identify the maximum possible value of $A$ for different threshold values:

$$
A=\mathrm{SDA}_{\mathrm{T}}-\mathrm{SDA}_{\mathrm{noT}}-\text { noSDA }_{\mathrm{T}}
$$

where $\mathrm{SDA}_{\text {not }}$ is the area not covered by the threshold value within the $5 \mathrm{~km}$ SDA.

The area predicted by the upland threshold value selected for each climatic index was then recalculated 
using the upper and lower 95\% confidence intervals for each climatic variable to estimate an upper and lower limit for the upland area. Therefore, in this approach, uncertainty in the location of the uplandlowland threshold was expressed in terms of the uncertainty in the climate data rather than uncertainty in the threshold value. This approach better represents the fact that environmental boundaries are not sharp transitions from one climate to another.

UKCIP02 climate projections were applied as a factorial (a) or difference $(b)$ change to the observed baseline 5 km gridded climate data (1961-1990) using standard statistical transformation to the mean and variance of each monthly climate variable:

where

$$
E(a X+b)=a E(X)+b
$$

$$
V(a X+b)=a^{2} V(X)
$$

Simple spatial downscaling was used, such that the climate change applied to each of the observed data points within each $5 \mathrm{~km}$ grid cell was taken from the value for the overlying $50 \mathrm{~km}$ grid cell from the UKCIP02 model output (Kilsby et al. 2007).

Changes in the altitudinal range of the area classed as uplands by different climatic indices were assessed. A $5 \mathrm{~km}$ digital elevation model (DEM) was produced by averaging the Ordnance Survey/EDINA 50 m DEM over each $5 \mathrm{~km}$ grid cell to produce a DEM at the same resolution as the climate data. Although the maximum altitude decreased and minimum altitude increased, comparison between altitudes within the SDA from a $500 \mathrm{~m}$ DEM and a $5 \mathrm{~km}$ DEM showed only a slight change in the median and inter-quartile range of the altitudinal data (Fig. 2). Therefore, the $5 \mathrm{~km}$ DEM provided a reasonable approximation of average altitude at a national scale.

Analysis was carried out using ESRI ArcView 9.2 and R (v.2.7.2) (R Core Development Team 2008) using sp, maptools and rgdal (Bivand et al. 2008), adehabitat (Calenge 2006) and lattice (Sarkar 2008) packages.

\section{RESULTS}

\subsection{Quantifying the difference between upland and lowland climates}

For the baseline period 1961-1990, the cool upland climate was quantified by a mean annual temperature of $7.1^{\circ} \mathrm{C}$ averaged across the SDA (range $=1.7$ to $10.3^{\circ} \mathrm{C}$ across all $5 \mathrm{~km}$ grid cells), which is about $2^{\circ} \mathrm{C}$ lower than the mean annual temperature across lowland areas outside of the SDA (mean $=9.2^{\circ} \mathrm{C}$, range $=$ 6.9 to $11.5^{\circ} \mathrm{C}$ ) (Table 4 ). Spatially, mean annual temperature (Fig. 3a) followed an altitudinal gradient and

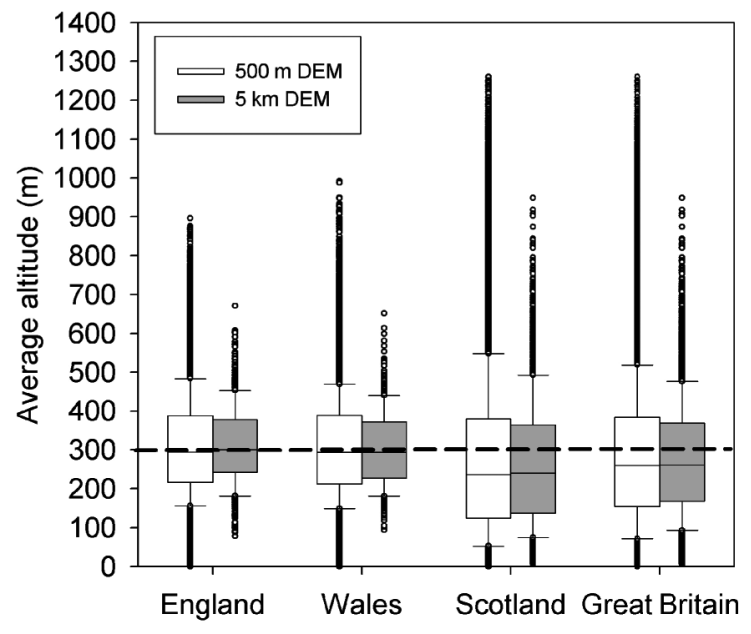

Fig. 2. Difference between altitudinal ranges within the Severely Disadvantaged Area across England, Wales, Scotland and Great Britain for a $500 \mathrm{~m}$ and $5 \mathrm{~km}$ digital elevation model (DEM). Ordnance Survey/EDINA elevation and boundary data were used

a north-south gradient, with the lowest temperatures seen at the highest altitudes towards the north (Grace \& Unsworth 1988, Hossell et al. 2003). The wet upland climate was quantified in terms of total annual precipitation of $1455 \mathrm{~mm} \mathrm{yr}^{-1}$ averaged across the SDA $\left(\right.$ range $=633$ to $4134 \mathrm{~mm} \mathrm{yr}^{-1}$ ), which is $82 \%$ greater than the total annual precipitation averaged across the lowland areas outside of the SDA (798 $\mathrm{mm} \mathrm{yr}^{-1}$, range $=507$ to $3325 \mathrm{~mm} \mathrm{yr}^{-1}$ ). Unlike temperature, total precipitation had a strong west-east gradient (Fig. 3b), with the greatest precipitation on the western side of the country closest to the Atlantic Ocean (Ratcliffe \& Thompson 1988, Hossell et al. 2003).

\subsection{Relationship between climate variables used in the indices and other climate variables}

Climatic indices used in the present study to define the upland environment were based on measured climate variables: precipitation, mean temperature, raindays and sunshine hours. As many climate variables are correlated, it is difficult to know whether the climate variables selected correctly define the key climatically limiting conditions for vegetation and soil formation. Results of the correlation analysis are shown in Table 5. Both mean annual temperature and annual accumulated temperature (calculated from monthly temperature data) were highly correlated with growing degree days and growing season length (calculated from daily temperature data) ( $\mathrm{r}>0.95$ ), and therefore provide a good indication of climatic conditions known to influence plant growth when daily data are not available. Maximum temperature provided the 


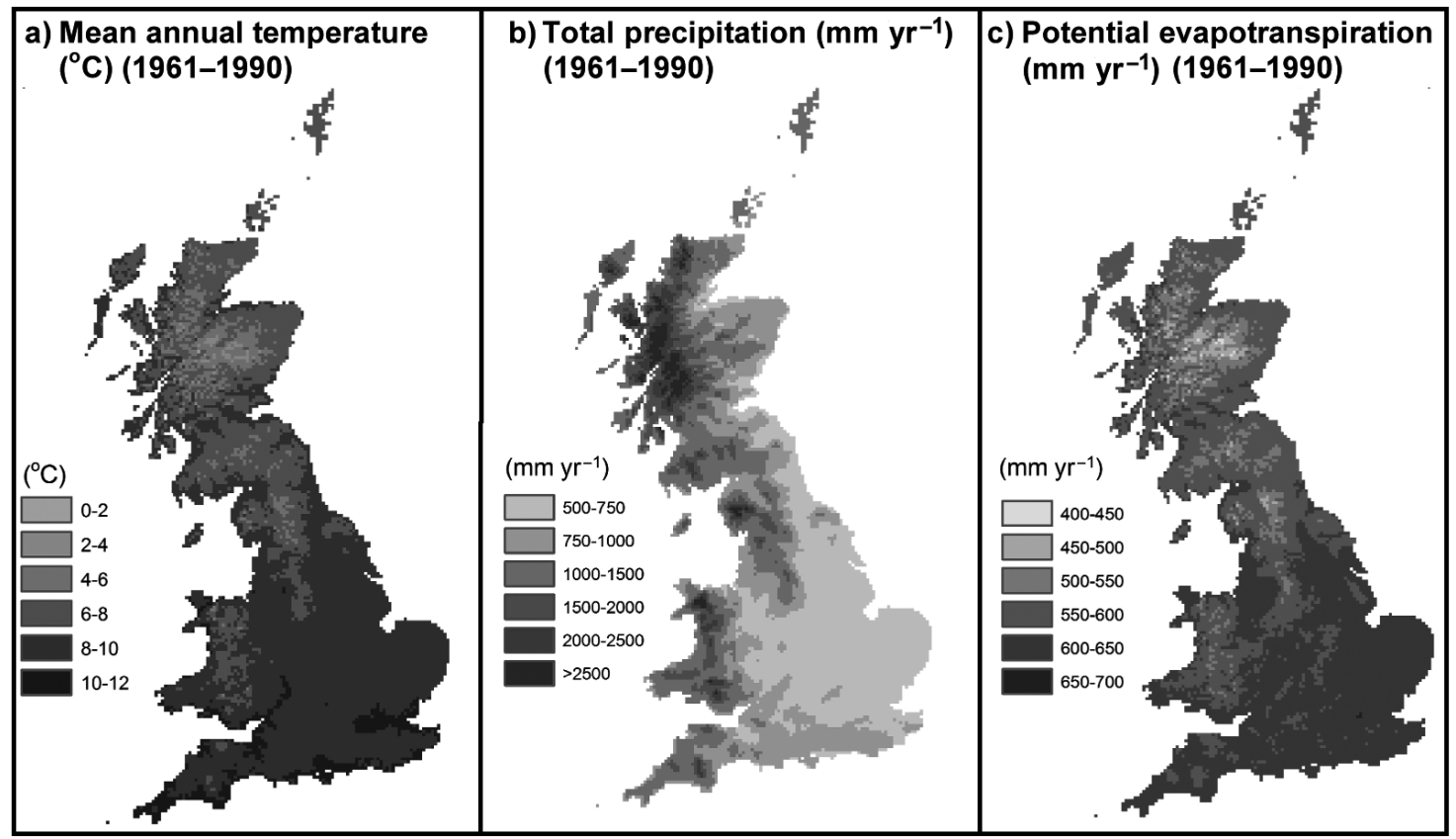

Fig. 3. (a) Mean annual temperature, (b) total precipitation and (c) potential evapotranspiration (using the Thornthwaite equation) across Great Britain for the baseline period 1961-1990. Met Office/UKCIP 5 km gridded climate data (Perry \& Hollis 2005) were used

strongest correlation with the number of dry days $(\mathrm{r}=$ $0.86)$ and was inversely related to raindays $(\mathrm{r}=-0.67)$. In contrast, minimum temperature showed little relationship with the number of raindays $(\mathrm{r}=0.06)$. As noted above, raindays were also inversely correlated with the number of sunshine hours ( $\mathrm{r}=-0.69)$, as would be expected due to cloud cover during times of rainfall. Persistent wet conditions could limit plant growth by controlling the number of sunshine hours and amount of photosynthetically active radiation. It is important to note that this analysis was based on the relationships between climate data from 1961-1990. It is possible that these relationships may change over time under changing climatic conditions.

\subsection{Defining upland environments from simple climatic indices and 1961-1990 baseline data}

All climatic indices $\left(\mathrm{CS}, \mathrm{MCS}_{\mathrm{r}}, \mathrm{MCS}_{\mathrm{S}}, \mathrm{TMI}\right.$ and AAMWD) derived using the 1961-1990 baseline climate data were fitted to the SDA map to determine a

Table 5. Correlation matrix for climatic variables from the baseline period (1961-1990) for each grid cell that falls within the Severely Disadvantaged Area (SDA) using Spearman's rank correlation coefficients. A summary of climate variables are shown in Table 4. ns: correlation not significantly different from zero ( $p>0.05$ ); Temp (acc): accumulated temperature (see Eq. 2); Sun (acc): accumulated number of sunshine hours in a year; GDD: growing degree days; GSL: growing season length. $\mathrm{N}=3838$

\begin{tabular}{|c|c|c|c|c|c|c|c|c|c|c|c|c|}
\hline & $\begin{array}{l}\text { Temp } \\
\text { (mean) }\end{array}$ & $\begin{array}{l}\text { Temp } \\
(\max )\end{array}$ & $\begin{array}{l}\text { Temp } \\
\text { (min) }\end{array}$ & $\begin{array}{l}\text { Temp } \\
\text { (acc) }\end{array}$ & GDD & GSL & Sun & $\begin{array}{l}\text { Sun } \\
(\mathrm{acc})\end{array}$ & Cloud & $\begin{array}{l}\text { Dry } \\
\text { days }\end{array}$ & $\begin{array}{l}\text { Rain } \\
\text { days }\end{array}$ & $\begin{array}{c}\text { Rain } \\
\text { intensity }\end{array}$ \\
\hline Temp (mean) & 1 & & & & & & & & & & & \\
\hline Temp (max) & 0.719 & 1 & & & & & & & & & & \\
\hline Temp (min) & 0.851 & 0.311 & 1 & & & & & & & & & \\
\hline Temp (acc) & 1.000 & 0.721 & 0.312 & 1 & & & & & & & & \\
\hline GDD & 0.969 & 0.823 & 0.741 & 0.969 & 1 & & & & & & & \\
\hline GSL & 0.952 & 0.529 & 0.933 & 0.951 & 0.878 & 1 & & & & & & \\
\hline Sun & 0.667 & 0.714 & 0.424 & 0.668 & 0.732 & 0.523 & 1 & & & & & \\
\hline Sun (acc) & 0.667 & 0.714 & 0.424 & 0.668 & 0.732 & 0.522 & 1.000 & 1 & & & & \\
\hline Cloud & -0.344 & -0.413 & -0.202 & 0.713 & -0.432 & -0.218 & -0.598 & -0.600 & 1 & & & \\
\hline Dry days & 0.711 & 0.861 & 0.409 & 0.713 & 0.825 & 0.550 & 0.838 & 0.839 & -0.634 & 1 & & \\
\hline Rain days & -0.277 & -0.669 & 0.063 & -0.278 & -0.384 & -0.071 & -0.690 & -0.691 & 0.411 & -0.614 & 1 & \\
\hline Rain intensity & -0.038 & -0.171 & 0.074 & -0.038 & -0.038 & 0.021 & -0.217 & -0.216 & -0.126 & $0.000^{\mathrm{ns}}$ & 0.629 & 1 \\
\hline Total precipitation & -0.046 & -0.295 & 0.149 & -0.345 & -0.088 & 0.071 & -0.379 & -0.379 & 0.106 & -0.188 & 0.789 & 0.897 \\
\hline
\end{tabular}


threshold distinguishing upland from lowland areas. $\mathrm{CS}$ and $\mathrm{MCS}_{\mathrm{r}}$ provided the best fit to the SDA, predicting 96 and $96.5 \%$, respectively, of the SDA area, and resulted in the smallest predicted area that fell outside of the SDA area (equivalent to 17.2 and $21.8 \%$, respectively, of the SDA mapped area) (Table 6, Fig. 4a-c). The threshold chosen for CS (>0.049) was lower than that chosen by Averis et al. (2004) (>0.15), most likely due to differences in the data sets and time periods used. The modified CS index calculated using the sunshine data $\left(\mathrm{MCS}_{\mathrm{S}}\right)$ seemed to provide poor delineation of upland areas (Fig. 4d), capturing less than $50 \%$ of the SDA with an exceptionally large range in area covered when using the upper and lower 95\% confidence intervals (covering nearly all the UK at the lower confidence interval). Therefore, substitution of total precipitation for raindays provided a better representation of upland environments than substitution with sunshine hours. This implies that the distribution and amount of rainfall across the year is a more important climatic factor defining upland environments and habitats within GB than the amount of sunshine and/or photosynthetically active radiation.

In terms of the mapped extent of upland areas, the lower limit for the CS covered a larger area of southwest England, Cheshire and Lancashire than the $\mathrm{MCS}_{\mathrm{r}}$, whereas the lower limit for the $\mathrm{MCS}_{\mathrm{r}}$ appeared to pick out some of the higher-altitude areas across central and southern England. The lower limit of $\mathrm{MCS}_{\mathrm{r}}$ also highlighted an altitudinal gradient, similar to the pattern in mean annual temperature (Fig. 3a), rather than a west-east gradient, similar to the pattern in total annual precipitation (Fig. 3b). These subtle differences in present spatial extent predicted by the indices will infer different spatial results for projected future change in upland areas calculated with each index.

Both TMI and AAMWD also showed a reasonable fit to the SDA map, predicting $94 \%$ of the SDA area; how- ever, the area predicted that falls outside of the SDA (26.6 and $37.9 \%$ of the SDA area, respectively) was larger for both of these indices than that predicted by both the CS and $\mathrm{MCS}_{\mathrm{r}}$. Both TMI and AAMWD appeared to show a stronger west-east gradient than $\mathrm{CS}$ and $\mathrm{MCS}_{\mathrm{r}}$, as larger areas of southwest England and smaller areas of the North York Moors, for instance, were included above the threshold (Fig. 4e,f). Interestingly, a wider area of lowland England was covered by the AAMWD than any other index, excluding $\mathrm{MCS}_{\mathrm{S}}$, which did not provide a good fit to upland areas. AAMWD captured the seasonality in water balance, whereas TMI is based on the annual water balance. Although both TMI and AAMWD were more hydrologically meaningful indices than the CS and $\mathrm{MCS}_{\mathrm{r}}$, they were less able to represent upland areas as defined by the SDA. As other definitions of upland areas generally cover a smaller area than that captured within the SDA (Fig. 1), additional areas that could be classed as upland environment outside of the SDA seem unlikely.

\subsection{Historic and future projected changes in upland environments}

Historic changes in the upland area predicted by $\mathrm{MCS}_{\mathrm{r}}, \mathrm{TMI}$ and AAMWD were assessed from the observed data (1921-2000) and future projections under UKCIP02 high and low emissions scenarios (2010-2100). CS could not be used in this analysis as future raindays were not available directly from UKCIP02 at a national scale; $\mathrm{MCS}_{\mathrm{S}}$ was not used due to the poor fit to the SDA map (Fig. 4d).

All 3 climatic indices showed an overall decline in the area defined by that index as an upland environment over time, although the magnitude and spatial extent of the remaining upland area varied between each climatic index (Figs. $5 \& 6$ ). Over the recent observed period, $\mathrm{MCS}_{\mathrm{r}}$ showed very little change in the upland area, in contrast to AAMWD and TMI, which showed a decline of 15 and 5\% from 1931-1960 to 1961-1990, respectively (Fig. 6). The decline in upland area for the AAMWD and TMI indices imply that the climate across some areas has become drier owing to changes in the balance between precipitation and potential evaporation.

By contrast, $\mathrm{MCS}_{\mathrm{r}}$ showed the greatest decline in area under future climate projections, with

\begin{tabular}{lccccc}
$\begin{array}{l}\text { Climatic } \\
\text { index }\end{array}$ & Threshold & $\begin{array}{c}\text { Area as \% of } 5 \mathrm{~km} \mathrm{SDA} \\
\text { Area in SDA }\end{array}$ & $\begin{array}{r}\text { Area not } \\
\text { in SDA }\end{array}$ & $\begin{array}{r}\text { Tsing mean } \\
\text { climate data }\end{array}$ & $\begin{array}{c}\text { Using } 95 \% \text { confi- } \\
\text { dence interval of } \\
\text { mean climate data }\end{array}$ \\
\hline $\mathrm{CS}$ & $\geq 0.049$ & 96.0 & 17.2 & 108575 & $(78475 ; 144725)$ \\
MCS $_{\mathrm{r}}$ & $\geq 0.0022$ & 96.5 & 21.4 & 113000 & $(85650 ; 143250)$ \\
MCS $_{\mathrm{S}}$ & $\geq 0.45$ & 47.1 & 19.2 & 63550 & $(9375 ; 221225)$ \\
TMI & $\geq 0.32$ & 93.9 & 37.9 & 126450 & $(91875 ; 169300)$ \\
AAMWD & $\geq-104$ & 94.0 & 36.6 & 125325 & $(79075 ; 187450)$ \\
\hline
\end{tabular}

Table 6. Optimised threshold values and corresponding area predicted for climatic incovering the Severely Disadvantaged Area (SDA) map using 1961-1990 baseline lated using raindays and sunshine data, respectively; TMI: Thornthwaite-Mather index; AAMWD: annual accumulated water monthly deficit. NB: total area of the SDA is $96900 \mathrm{~km}^{2}$ 


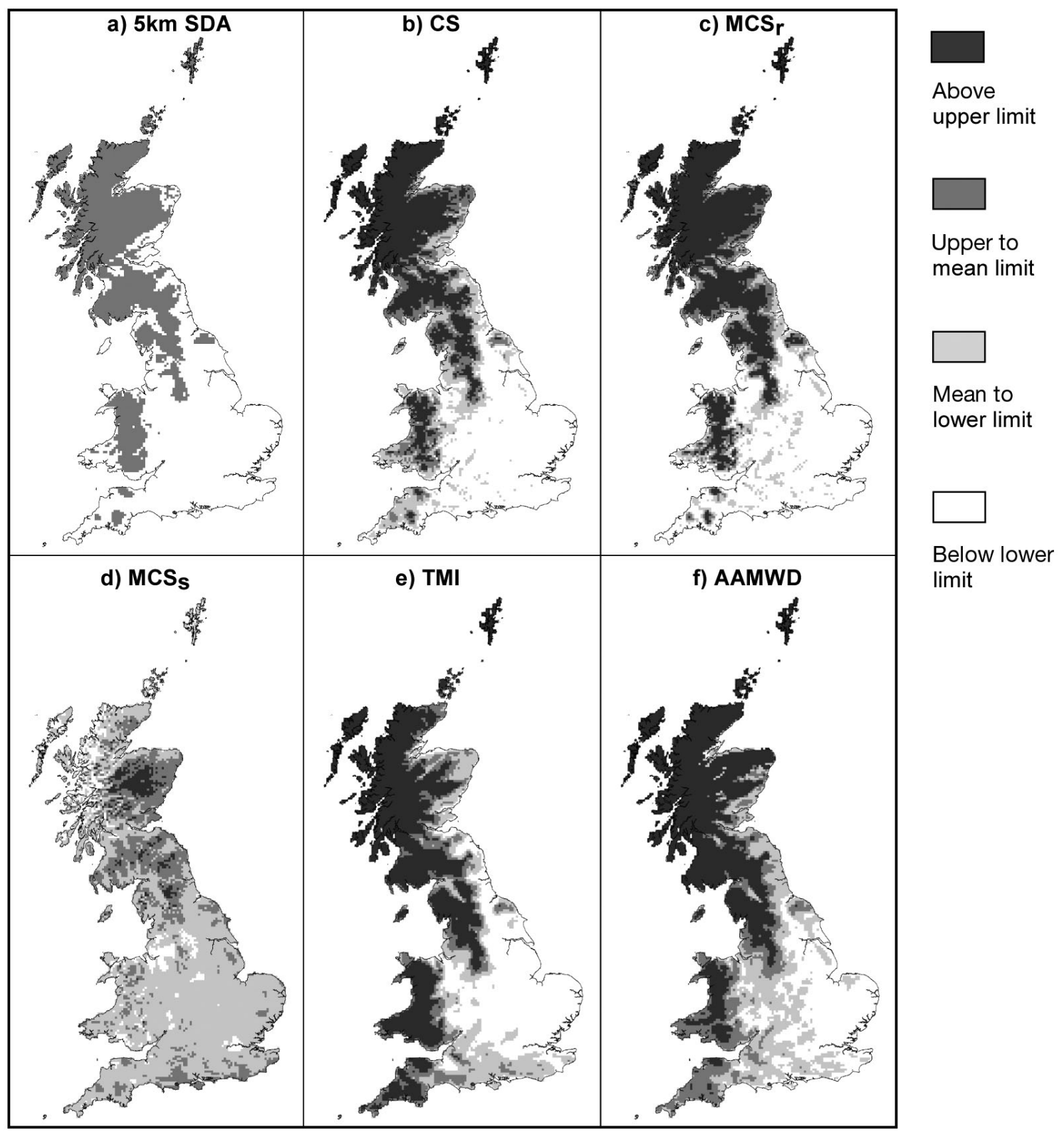

Fig. 4. Upland areas defined by (a) the $5 \mathrm{~km}$ Severely Disadvantage Area (SDA) and 5 climatic indexes: (b) the climate severity in$\operatorname{dex}(\mathrm{CS}) ;(\mathrm{c})$ a modified CS index calculated using raindays data $\left(\mathrm{MCS}_{\mathrm{r}}\right)$; (d) a modified CS index calculated using sunshine data $\left(\mathrm{MCS}_{\mathrm{S}}\right)_{;}(\mathrm{e})$ the Thornthwaite-Mather index (TMI); and (f) the annual accumulated water monthly deficit (AAWMD) (see Table 6). The mean limit and the upper and lower limits were calculated using the mean and the upper and lower $95 \%$ confidence intervals, respectively, of each climate variable used within each climatic index. OCrown Copyright/database right 2009. An Ordnance Survey/EDINA supplied service. SDA data for England @Crown Copyright. All rights reserved 2010. Data for Wales were provided by The Welsh Assembly Government, Department of Rural Affairs. Data for Scotland were reproduced under the terms of the Click-Use Licence. Met Office/UKCIP gridded climate data

the upland area shrinking by 51 and $84 \%$ from 1961-1990 to the 2080s under the low and high emissions scenarios, respectively (Fig. 6, Table 7). AAMWD showed a similar magnitude of change as did $\mathrm{MCS}_{\mathrm{r}}$ (35 and 69\% decline, respectively), but the pattern of retreat in the 'climate space' (i.e. the area projected by the climatic index that represents upland environments) differed. For $\mathrm{MSC}_{\mathrm{r}}$, the climate space retreated to high-altitude areas, reflecting the influence of altitude on temperature; for AAMWD, the climate space declined in eastern areas, following the west-east gradient in precipitation (Figs. 3 \& 5). TMI showed a much smaller decline in upland area (13 and 24\% for low and high emissions scenarios, respectively, by the 


\section{MCS}
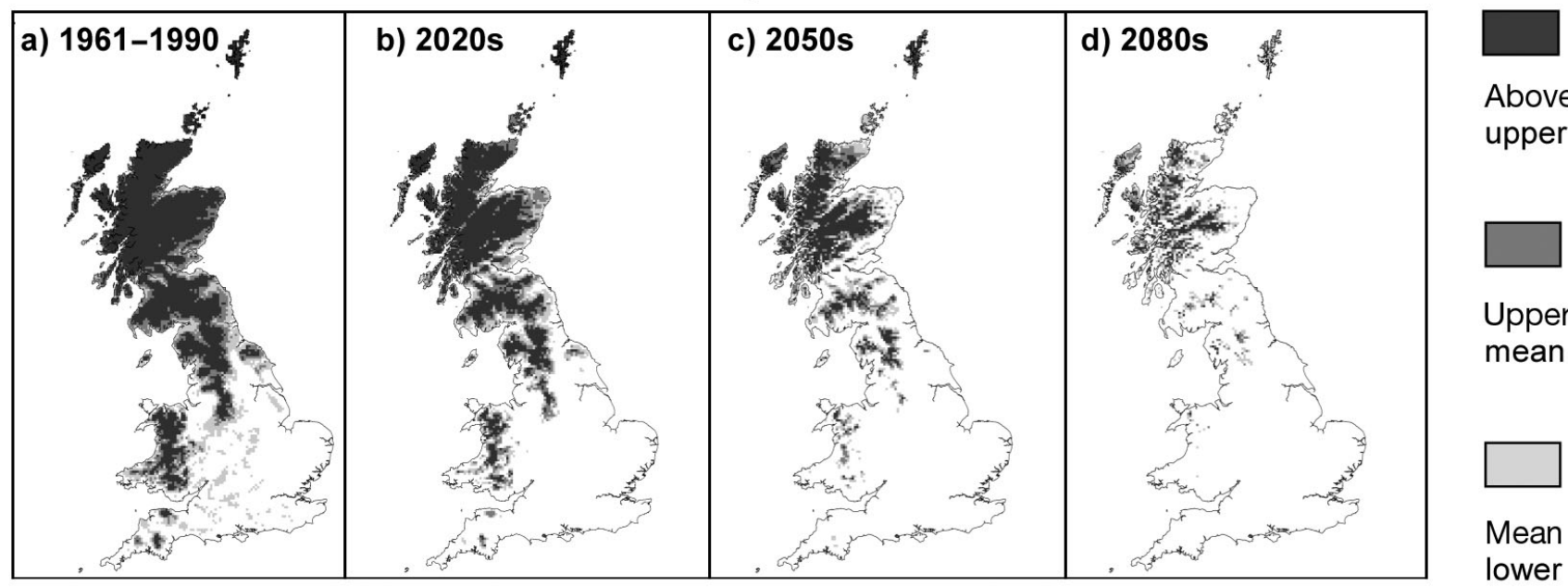

Above

upper limit

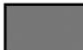

Upper to mean limit

TMI

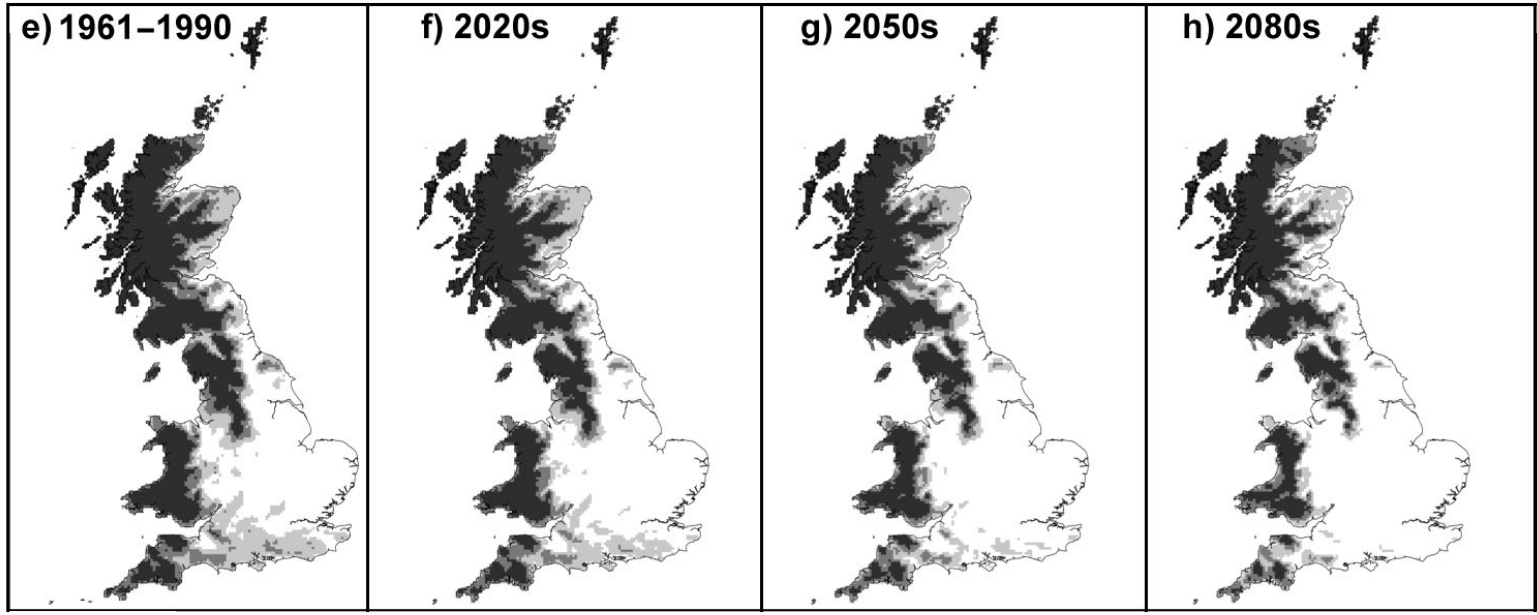

Below lower limit

Mean to lower limit

AAMWD

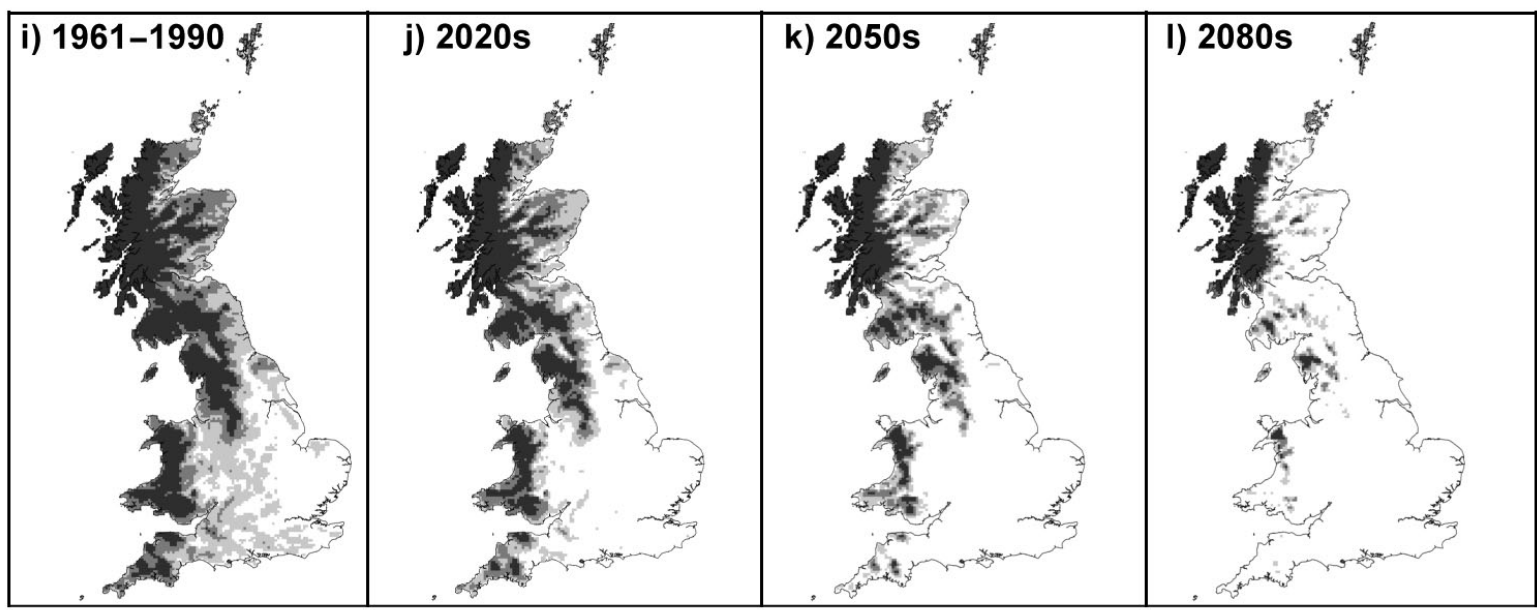

Fig. 5. Changes in upland areas under UKCIP02 for 3 climatic indexes (MCS ${ }_{\mathrm{r}}$ TMI, AAMWD) under the high emissions scenario. The mean and the upper and lower limits were calculated using the mean and the upper and lower $95 \%$ confidence intervals of the mean value of each climate variable used within each climatic index. OCrown Copyright/database right 2009. An Ordnance Survey/EDINA supplied service. Met Office/UKCIP gridded climate data. UKCIP02 @ Crown Copyright 2002 

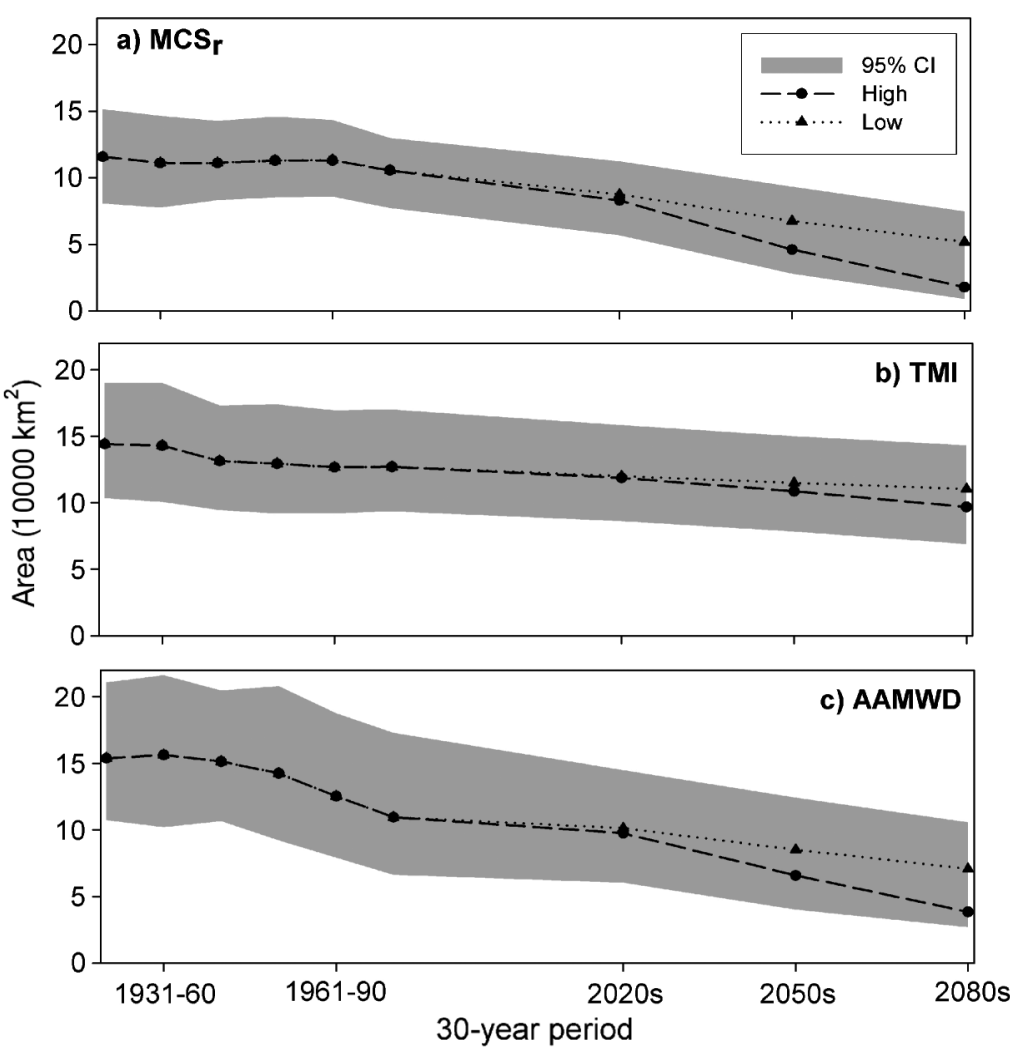

Fig. 6. Change in the upland area as classified by the Severely Disadvantaged Area (SDA) using 3 climatic indexes, (a) $\mathrm{MCS}_{\mathrm{r}}$, (b) TMI and (c) AAMWD, under 2 UKCIP02 emission scenarios (high and low). Data points show the areas covered as calculated using the mean of each climate variable within each climatic index. The grey area shows the upper and lower limits of the area covered calculated using the upper and lower $95 \%$ confidence intervals of the mean value of each climate variable within each climatic index 2080s), although the pattern of retreat followed a pattern similar to that of AAMWD, with retreat towards the west, following the west-east gradient in precipitation.

\subsection{Relationship between upland environments and altitude}

Regions in GB are considered to be either upland or lowland, hence the boundary between upland and lowland areas represents both the lower limit of upland areas and the upper limit of lowland areas. The upland-lowland transition can be an important zone in terms of agricultural potential and changing growing season length. Historically changing use of these areas is believed to be linked to climate (Leighton 1997). Whereas upland areas are intuitively associated with high-altitude areas, the environment found in high-altitude areas in southern England is also found at low altitudes in northern Scotland and along the west coast. Within the SDA, altitudes range from $<5$ to $>948 \mathrm{~m}$ (Table 4 ); therefore, there is no apparent altitudinal threshold that delineates these areas as uplands as they are found across all altitudes in GB. By con-

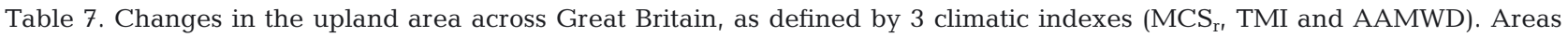
shown in brackets are the range calculated using the upper and lower 95\% confidence intervals of the mean for each climate variable by each climate index. NB: total area of the Severely Disadvantaged Area is $96900 \mathrm{~km}^{2}$

\begin{tabular}{|c|c|c|c|c|c|}
\hline \multirow{2}{*}{$\begin{array}{l}\text { Climate index/ } \\
\text { emissions scenario }\end{array}$} & \multicolumn{5}{|c|}{ - Upland area from $5 \mathrm{~km}$ grid $\left(\mathrm{km}^{2}\right)$} \\
\hline & $1931-1960$ & $1961-1990$ & $2020 s$ & $2050 \mathrm{~s}$ & $2080 \mathrm{~s}$ \\
\hline $\mathrm{MCS}_{\mathrm{r}}$ & $\begin{array}{c}111225 \\
(77450 ; 146450)\end{array}$ & $\begin{array}{c}113000 \\
(85650 ; 113000)\end{array}$ & & & \\
\hline High & & & $\begin{array}{c}82925 \\
(56600 ; 107375)\end{array}$ & $\begin{array}{c}46000 \\
(27750 ; 66750)\end{array}$ & $\begin{array}{c}17725 \\
(8800 ; 29300)\end{array}$ \\
\hline Low & & & $\begin{array}{c}87500 \\
(60475 ; 112275)\end{array}$ & $\begin{array}{c}67600 \\
(45150 ; 93175)\end{array}$ & $\begin{array}{c}51750 \\
(32025 ; 74675)\end{array}$ \\
\hline TMI & $\begin{array}{c}142725 \\
(100475 ; 189875)\end{array}$ & $\begin{array}{c}126450 \\
(91875 ; 126450)\end{array}$ & & & \\
\hline High & & & $\begin{array}{c}118550 \\
(85925 ; 156125)\end{array}$ & $\begin{array}{c}108575 \\
(78100 ; 140500)\end{array}$ & $\begin{array}{c}96725 \\
(68800 ; 125100)\end{array}$ \\
\hline Low & & & $\begin{array}{c}119800 \\
(86750 ; 158125)\end{array}$ & $\begin{array}{c}114825 \\
(83325 ; 149750)\end{array}$ & $\begin{array}{c}110325 \\
(79475 ; 143075)\end{array}$ \\
\hline AAMWD & $\begin{array}{c}156250 \\
(105150 ; 216075)\end{array}$ & $\begin{array}{c}125325 \\
(79075 ; 125325)\end{array}$ & & & \\
\hline High & & & $\begin{array}{c}97525 \\
(60150 ; 139775)\end{array}$ & $\begin{array}{c}65775 \\
(40075 ; 98425)\end{array}$ & $\begin{array}{c}38350 \\
(26675 ; 55850)\end{array}$ \\
\hline Low & & & $\begin{array}{c}101375 \\
(63350 ; 144825)\end{array}$ & $\begin{array}{c}85150 \\
(52850 ; 124150)\end{array}$ & $\begin{array}{c}70850 \\
(43575 ; 105625)\end{array}$ \\
\hline
\end{tabular}


Table 8. Changes in the mean altitude of upland areas across Great Britain, as defined by 3 climatic indexes $\left(\mathrm{MCS}_{\mathrm{r}}\right.$ TMI and AAMWD). Mean value represents the average altitude across all grid cells for each climate index calculated using mean climate variable. Altitude shown in brackets is the range for the average altitude covered by each climate index calculated using the upper and lower 95\% confidence intervals of the mean for each climate variable used. DEM: digital elevation model

\begin{tabular}{|lccccc}
\hline \multirow{2}{*}{$\begin{array}{l}\text { Climate index/ } \\
\text { emissions scenario }\end{array}$} & $1931-1960$ & $1961-1990$ & $2020 \mathrm{~s}$ & $2050 \mathrm{~s}$ & \\
\cline { 2 - 4 } & $265(237-299)$ & $262(232-296)$ & & \\
MCS & & & $298(268-342)$ & $357(319-411)$ & $440(387-506)$ \\
High & & $292(263-335)$ & $320(284-364)$ & $348(308-396)$ \\
Low & $238(205-275)$ & $244(210-272)$ & & & \\
TMI & & $250(219-277)$ & $257(232-283)$ & $265(244-290)$ \\
High & & $249(217-276)$ & $252(224-278)$ & $255(230-282)$ \\
Low & $226(190-268)$ & $244(198-285)$ & & & \\
AAMWD & & $269(233-303)$ & $297(268-306)$ & $284(277-293)$ \\
High & & $266(229-301)$ & $282(245-308)$ & $294(260-311)$ \\
Low & & & & &
\end{tabular}

trast, the altitudinal range of areas outside of the SDA is $<5$ to $288 \mathrm{~m}$ (Table 4 ). Hence, the altitudinal threshold of $300 \mathrm{~m}$ marking the upland-lowland transition (Atherden 1992) is perhaps more appropriate in terms of defining the upper limit of lowland environments rather than the lower limit of upland environments.

The climatic indices covered a wider area and slightly lower altitude than the SDA map across the baseline period (1961-1990). For instance, 64\% of the area covered was at altitudes $<300 \mathrm{~m}$ for $\mathrm{MCS}_{\mathrm{r}}$ whereas $60 \%$ of areas within the SDA were at altitudes $<300 \mathrm{~m}$. Overall, the $\mathrm{MCS}_{\mathrm{r}}$ had the highest average altitude (262 $\mathrm{m}$ ) and TMI and AAMWD were the lowest $(244 \mathrm{~m})$ (Table 8$)$, although all were lower than the average altitude of the SDA of $278 \mathrm{~m}$. The lower mean upland altitude corresponded to a lower value for the upper limit of lowland areas defined by each climatic index, which was 37 to $68 \mathrm{~m}$ lower than the actual $288 \mathrm{~m}$ upper limit of lowland areas outside of the SDA (Table 4).
Under historic and future climatic projections, the average altitude within the defined upland area increased as the climate space decreased. Between 1931-1960 and 1961-1990, MCS r showed little change in average altitude, consistent with little change in area (Figs. 6 \& 7). In contrast, both TMI and AAMWD showed an increase in average altitude over the same period. However, under future climate projections, $\mathrm{MCS}_{\mathrm{r}}$ showed the greatest increase in average altitude (+175 $\mathrm{m}$ by the 2080s relative to 1961-1990 baseline period under UKCIP02 high emissions), with both mean and median values shifting from $<300$ to $>300 \mathrm{~m}$. For both TMI and AAMWD, the mean and median altitude remained below $300 \mathrm{~m}$, with increases of +21 and +40 m, respectively, by the 2080s relative to 1961-1990 baseline period (UKCIP02 high emissions) (Table 8). As $\mathrm{MCS}_{\mathrm{r}}$ showed retreat to high-altitude areas, it follows that this index should show a greater increase in average altitude than the TMI and AAMWD, which

Table 9. Changes in the upper altitudinal limit of lowland areas across Great Britain, as defined by 3 climatic indexes (MCS , TMI $^{2}$ and AAMWD). Lowland areas were defined as areas below the upland threshold value (Table 6). The upper altitudinal limit was defined as the 0.99 quartile rather than maximum value to remove bias from spurious individual values. Altitude was determined from the climatic index calculations based on mean climate data, with the altitude shown in brackets from the climate indexes calculated using the upper and lower $95 \%$ confidence intervals of the mean for each climate variable used. DEM: digital elevation model

\begin{tabular}{|c|c|c|c|c|c|}
\hline \multirow{2}{*}{$\begin{array}{l}\text { Climate index/ } \\
\text { emissions scenario }\end{array}$} & \multirow[b]{2}{*}{ 1931-1960 } & \multicolumn{3}{|c|}{ — Upper lowland altitude limit from 5 km DEM (m) } & \multirow[b]{2}{*}{$2080 s$} \\
\hline & & 1961-1990 & $2020 s$ & $2050 \mathrm{~s}$ & \\
\hline $\mathrm{MCS}_{\mathrm{r}}$ & $311(226-379)$ & $220(167-274)$ & & & \\
\hline High & & & $300(240-354)$ & $387(351-431)$ & $470(436-520)$ \\
\hline Low & & & $283(228-348)$ & $339(281-379)$ & $373(332-418)$ \\
\hline TMI & $261(171-372)$ & $245(157-367)$ & & & \\
\hline High & & & $271(180-391)$ & $313(209-416)$ & $361(260-457)$ \\
\hline Low & & & $266(175-385)$ & $288(193-401)$ & $306(206-415)$ \\
\hline AAMWD & $226(142-359)$ & $251(129-401)$ & & & \\
\hline High & & & $336(215-461)$ & $440(346-559)$ & $577(485-615)$ \\
\hline Low & & & $323(197-451)$ & $367(275-487)$ & $416(327-530)$ \\
\hline
\end{tabular}




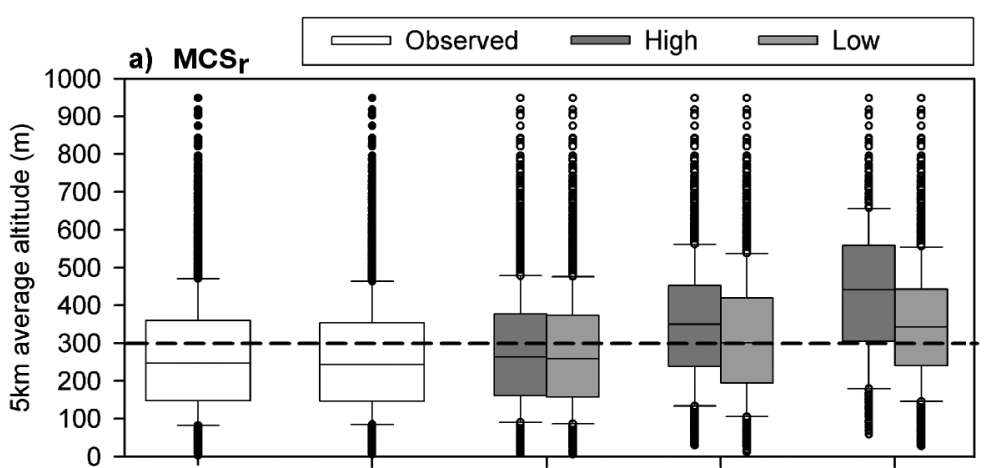

b) TMI

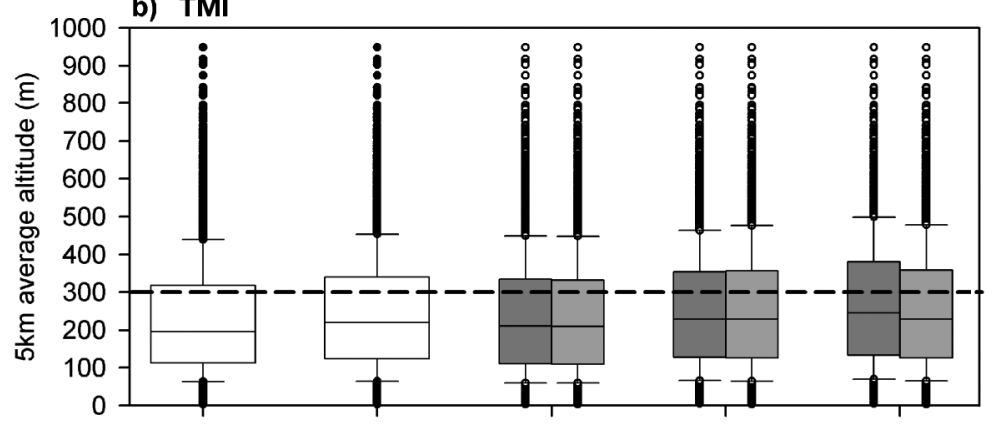

c) AAMWD

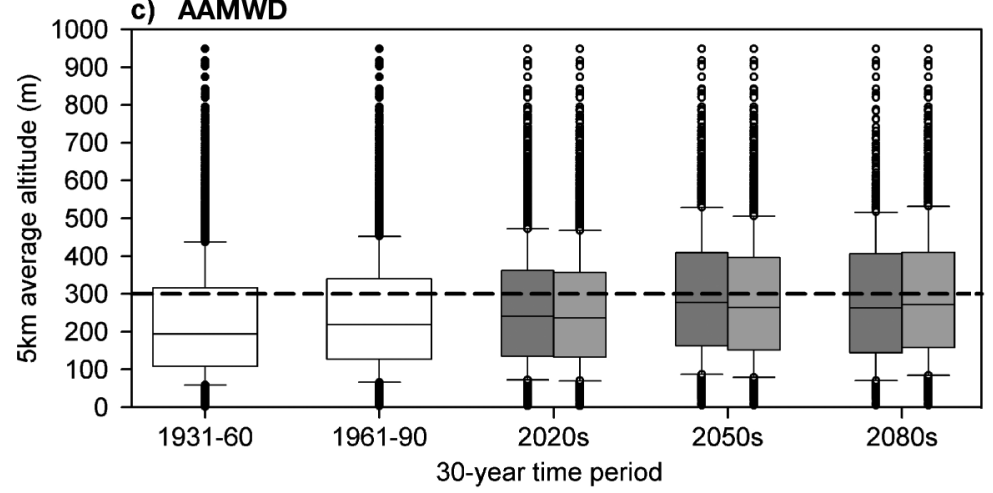

Fig. 7. Change in altitudinal range of areas classified as upland environments using 3 climatic indexes, (a) $\mathrm{MCS}_{\mathrm{r}}$ (b) TMI and (c) AAMWD, under 2 UKCIP02 emission scenarios (high and low). Dashed line represents the $300 \mathrm{~m}$ altitudinal threshold marking the upland-lowland transition. Altitudinal range shown for index calculations is based on mean climate data only

show retreat to westerly areas. Therefore, different climatic indices show differences in the area of retreat and overall altitudinal range depending on whether the index principally captured the cool or wet upland environment.

Similar increases in altitude were seen for the upper limit of the lowland area outside of the SDA (Table 9). However, increases in the upper limit of lowland areas were greater for AAMWD than for $\mathrm{MSC}_{\mathrm{r}}$, with increases of +326 and +250 m between 1961-1990 and the 2080s for the high emissions scenario, respectively, whereas TMI increased by $+126 \mathrm{~m}$ over the same period. Although the general trend from 1961-1990 onwards was for an increase in the upper limit of lowland areas, both $\mathrm{MCS}_{\mathrm{r}}$ and TMI showed a decrease in the upper limit from 1931 to 1960 of -91 and $-16 \mathrm{~m}$, respectively. Therefore, although all 3 climatic indices showed an increase in lowland area owing to a decrease in the upland area from 1921 to 1950 onwards (Fig. 6), the upper altitudinal limit of lowland areas has not always increased in response to a decrease in the upland area, even though the average altitude of upland areas has increased.

\section{DISCUSSION}

Upland climates are typically assumed to be characterised by a decrease in temperature and radiant energy and an increase in precipitation and wind speed with altitude (Grace \& Unsworth 1988). These factors influence plant growth and soil formation, with complex feedbacks between these processes (Avery 1990). For instance, cool and wet conditions slow down the rate of organic matter decomposition, thereby allowing organic matter to accumulate in peaty soils (Wieder \& Vitt 2006). High soil organic matter also promotes water retention and acidic conditions, which in turn favour acidic grassland, heath and bog vegetation. Warmer and/or drier conditions could encourage development of more vascular plants and grasses, which in turn dry out the wet organic soils and increase mineralisation and nutrient release, further encouraging these species at the expense of acidic and wet tolerant species (e.g. Berendse et al. 2001). Exploring such complex feedbacks would require dynamic processbased models that couple organic soils and vegetation dynamics. Currently, there are no such fully coupled models of vegetation and organic soils, as organic soil models are still in early stages of development (e.g. Smith et al. 2010, this Special). Until such models have been developed and fully tested, approaches such as simple climatic indices are needed for broad-scale climatic vulnerability assessments.

The challenge with developing a simple climatic index is to identify the main limiting climatic parameters for the ecosystem as a whole, when it is possible to fit any number of variables and/or combination of variables to coincide with contemporary maps of upland areas. Furthermore, as climates change, the relationship between ecosystems and limiting variables may also change. A climatic index providing a good delineation of contemporary environments may not represent the main limiting conditions in the future. In 
spite of these challenges, climate indices can provide an indication of where ecosystem change may be expected under future climate projections.

Climatic indices fitted to contemporary climate data (i.e. 1961-1990) suggest that growing season length (measured in terms of annual accumulated temperature) in combination with the amount of rainfall or number of raindays (CS and $\mathrm{MCS}_{\mathrm{r}}$ ) provided a better delineation of upland areas (as defined by the SDA) than measures of annual or seasonal water balance (TMI and AAMWD) or measures of photosynthetically limiting radiation (measured as number of sunshine hours) $\left(\mathrm{MCS}_{\mathrm{S}}\right)$. This suggests that growing season length and the distribution of rainfall during the year are more limiting climatic variables controlling the current distribution of upland habitats and soils than specific measures of water balance or radiation. In terms of future projections, climatic indices including growing season length $\left(\mathrm{CS}\right.$ and $\left.\mathrm{MCS}_{\mathrm{r}}\right)$ showed retreat to higher altitudinal areas. Although temperature and precipitation are both sensitive to changes in altitude, there was a stronger west-east gradient in the area predicted by the indices based on the annual and seasonal water balance (TMI and AAMWD). This was reflected in the retreat in the climate space calculated by these indices to western areas. Where upland environments occur at low altitudes, it seems wet conditions limit plant growth and soil development.

Assessment of change in upland environments using climatic indices indicates the potential vulnerability of some upland areas to projected changes in climate over the next 10 to $100 \mathrm{yr}$. All climatic indices project a decline in the upland environment defined by thresholds linking recent climate conditions (1961-1990 baseline) with the SDA. However, the pattern of this retreat varies between climatic indices. For instance, all indices showed a retreat in upland climate space over lower altitude areas in the east, and persistence of upland climate in high-altitude areas in the west. However, there was less agreement between indices in terms of the relative amount of change at high altitudes in central and eastern areas and at low altitudes in western areas. Therefore, in these areas, the comparative importance of change in temperature and precipitation for upland habitats is less certain. Water stress is not usually a limiting factor for upland plants (Grace \& Unsworth 1988), but reduction in available water through changes in precipitation and evaporation may have a greater indirect effect on vegetation by influencing soil wetness, which in turn can affect the rate of mineralisation and nutrient availability. It is worth noting that the balance between bryophyterich and lichen-dominated communities follows the west-east gradient in wetness (Ratcliffe \& Thompson 1988).
Correctly defining the threshold that marks the transition between upland and lowland environments is key to understanding the potential impact of climate change on these areas. Previous analysis of the climate associated with British habitats has shown that there is greater separation between the climates associated with upland and lowland habitats than between specific habitat types within either upland or lowland areas (Hossell et al. 2003). In spite of the ability of indices such as CS and $\mathrm{MCS}_{\mathrm{r}}$ to delineate contemporary upland conditions, the transition between upland and lowland areas occurs across a smaller area than that defined by the upper and lower limits presented here (especially for TMI and AAMWD). This transition from upland to lowland also occurs over comparatively small changes in temperature and precipitation. For instance, the mean annual temperature for much of the lowland areas outside the SDA in Britain is only 0 to $4^{\circ} \mathrm{C}$ greater than many upland areas (Fig. 3, Table 4). Many upland areas are likely to experience this magnitude of climate change over the next 50 to $100 \mathrm{yr}$ (Murphy et al. 2009). Gradients in total precipitation are larger, with upland areas having around twice the average annual precipitation than lowland areas (Table 4), although differences in the number of raindays are small.

Perhaps one of the greatest sources of confusion over defining upland areas is the assumption that they can be defined as land above $300 \mathrm{~m}$ (e.g. Atherden 1992), when upland areas are found across all altitudinal ranges (Table 4). Although the $300 \mathrm{~m}$ threshold is reasonable within specific areas, like northern England, it does not apply across the whole country, particularly in northern Scotland, where upland environments can be found at sea level (Averis et al. 2004). In contrast, the upper limit of lowland areas (defined in terms of areas outside of the GB SDA) is $12 \mathrm{~m}$ below the $300 \mathrm{~m}$ limit (Table 4). Therefore, the $300 \mathrm{~m}$ threshold is perhaps a more appropriate definition of the upper limit of lowland areas rather than the lower limit of upland areas.

In the present study, we determined the suitability of climatic indices to define upland environments using a threshold-based classification of their association with the EU SDA, which itself has been defined on the basis of physical and socioeconomic conditions. As vegetation cover in upland areas is heavily managed, it is difficult to use these maps to determine the area under natural equilibrium with the current climate. Therefore, it is uncertain whether the SDA is a fair representation of upland environments themselves. The SDA across Europe covers hot and arid as well as cool and wet areas where agricultural activity is also marginal. It is important to note that other factors contributing to low agricultural productivity or particular upland characteristics, such as shallow soils and steep slopes, 
will not change within the next $100 \mathrm{yr}$, regardless of changes in climate. Therefore, a distinction may need to be made between the areas where physical conditions are associated with organic soils that have developed over the last few thousand years and the areas where climate is the primary driver with habitats that will respond more quickly to change over decadal time scales. There are also limitations in the use of a threshold approach to define upland areas. Further research is needed to understand the uncertainty envelope of multiple climate and geomorphological factors that define our current upland areas. This will improve our assessments of change by better defining the sensitivity of these landscapes and this habitat formation to drivers of change.

Studies with projections of climate change data give a measure of exposure to climate change. Vulnerability is based on exposure and sensitivity to change. It is reasonable to expect that areas on the margins of the climate envelope might be more sensitive to change. But it should also be noted that sensitivity may be affected by local physical factors, e.g. unique topography that keeps down-slope areas wet or north-facing slopes cool compared to surrounding areas. Sensitivity can also be affected by management, with more highly managed or utilised areas being potentially more sensitive to climate change. Unproductive perennial vegetation, such as that found over much of upland Britain, may have greater resistance to climate change than vegetation of nutrient-rich habitats; even so, such stress-tolerant plant communities may eventually be altered by immigration and extinction, especially following extreme episodes (Grime et al. 2007). Therefore, studies based entirely on climate can only give an indication of potential vulnerability and do not comprise a full vulnerability assessment.

\section{CONCLUSIONS}

Climate indices are a valuable tool for rapidly assessing the exposure of climate-sensitive habitats and soils to climate change, and hence give an indication of potential vulnerability to climate change. In the present study, we examined the suitability of a range of climate indices to map changes in upland environments that are typically defined by cool and wet conditions. Climatic indices fitted to contemporary observed climate data (baseline period 1961-1990) suggest that growing season length (measured in terms of annual accumulated temperature) in combination with the amount of rainfall or number of raindays (CS and $\mathrm{MCS}_{\mathrm{r}}$ ), provide a robust delineation of upland areas as defined by the EU SDA in the GB. These indices gave somewhat better results than indices based on measures of annual or seasonal water balance (TMI and AAMWD), and were significantly better than measures of photosynthetically limiting radiation (measured as number of sunshine hours) $\left(\mathrm{MCS}_{\mathrm{S}}\right)$.

All climatic indices projected an overall decline in the area defined as an upland environment by that index over time, with lower-altitude areas towards the east more likely to experience change than higheraltitude areas to the west. However, the magnitude and spatial extent of the change in the climate space associated with upland environments varied significantly between climatic indices under future climate projections, in spite of the similarity of fit of these climate indices to the baseline climate data (1961-1990). The greatest source of uncertainty is the choice of climate projection used, hence any future projections should be interpreted with caution. Here, we use projections from only one GCM (HadCM3). In addition, it is also worth noting that our threshold-based climatic indices are based on static relationships, which may not hold under future climate change.

Our analysis suggests that the climatic characteristics of upland areas in GB may change over the next 100 yr. In particular, the climatic severity of SDA in Britain may lead to changes in typical upland habitats and agricultural activities. There is not yet sufficient scientific information to assess the impact of these climatic changes on the degree or rate of change of habitat type (Clark et al. 2010, Gallego-Sala et al. 2010, Smart et al. 2010, all this Special), soil carbon loss (Billett et al. 2010, this Special) and associated ecosystem services (Cornell 2010, Maltby 2010, this Special), or on how management may influence these changes. However, results such as these are useful to highlight areas of potential change to researchers for long-term monitoring and further studies, and to those who wish to manage land for a variety of services.

Acknowledgements. This research was funded by the Environment Agency (Science Project Sc070036) and NERC QUEST research programme, directly funding J.M.C. and J.I.H. J.M.C. was also supported by a fellowship from the Grantham Institute for Climate Change, Imperial College; J.F. was supported by NERC standard grant (NE/E0002242/1); and P.S. is a Royal Society-Wolfson Research Merit Award holder. We thank Defra, The Welsh Assembly Government Department of Rural Affairs, The Scottish Government, Natural England, The Countryside Council for Wales, Centre for Ecology and Hydrology, Met Office, UKCIP and Ordnance Survey/EDINA for use of their data; and the reviewers for their constructive comments. In particular, we thank the EA-QUEST Uplands network for their input in the development of this work at workshops and throughout the duration of the project (http://quest.bris.ac.uk/research/ wkg-gps/soil.html). 


\section{LITERATURE CITED}

Allen RG, Pereira LS, Raes D, Smith M (1998) Crop evapotranspiration. Guidelines for computing crop water requirements. FAO Irrigation and drainage paper 56. FAO, Rome

Atherden M (1992) Upland Britain: a natural history. Manchester University Press, Manchester

Averis A, Averis B, Birks J, Horsfield D, Thompson D, Yeo M (2004) An illustrated guide to British upland vegetation. Joint Nature Conservation Committee, Peterborough

Avery BW (1990) Soils of the British Isles. CAB International, Wallingford

Bagnouls F, Gaussen H (1957) Les climats biologique et leur classification. Ann Geogr 66:193-220

Berendse F, Van Breemen N, Rydin H, Buttler A and others (2001) Raised atmospheric $\mathrm{CO}_{2}$ levels and increased $\mathrm{N}$ deposition cause shifts in plant species composition and production in Sphagnum bogs. Glob Change Biol 7: 591-598

Berry PM, Dawson TP, Harrison PA, Pearson R, Butt N (2003) The sensitivity and vulnerability of terrestrial habitats and species in Britain and Ireland to climate change. J Nat Conserv 11:15-23

Billett MF, Charman DJ, Clark JM, Evans CD and others (2010) Carbon balance of UK peatlands: current state of knowledge and future research challenges. Clim Res 45: $13-29$

Bivand RS, Pebesma EJ, Gomez-Rubio V (2008) Applied spatial data analysis with R. Springer, New York, NY

Calenge C (2006) The package 'adehabitat' for the R software: a tool for the analysis of space and habitat use by animals. Ecol Model 197:516-519

Christensen JH, Carter TR, Rummukainen M, Amanatidis G (2007) Evaluating the performance and utility of regional climate models: the PRUDENCE project. Clim Change 81:1-6

Clark JM, Gallego-Sala AV, Allott TEH, Chapman S and others (2010) Assessing the vulnerability of blanket peat to climate change using an ensemble of statistical bioclimatic envelope models. Clim Res 45:131-150

Cornell S (2010) Valuing ecosystem benefits in a dynamic world. Clim Res 45:261-272

Feddema JJ (2005) A revised Thornthwaite-type global climate classification. Phys Geogr 26:442-466

Fielding AH, Haworth PF (1999) Upland habitats. Routledge, London

> Fowler HJ, Kilsby CG, O'Connell PE (2003) Modeling the impacts of climatic change and variability on the reliability, resilience, and vulnerability of a water resource system. Water Resour Res 39:1222

> Gallego-Sala AV, Clark JM, House JI, Orr HG and others (2010) Bioclimatic envelope model of climate change impacts on blanket peatland distribution in Great Britain. Clim Res 45:151-162

Grace J, Unsworth MH (1988) Climate and microclimate of the uplands. In: Usher MB, Thompson DBA (eds) Ecological change in the uplands. Blackwell, Oxford, p $137-149$

Gregory S (1954) Accumulated temperature maps of the British Isles. Trans Inst Br Geogr 20:59-73

Grime JP, Hodgson JA, Hunt R (2007) Comparative plant ecology: a functional approach to common British species, 2nd edn. Castlepoint Press, Dalbeattie

Hewitt CD, Griggs DJ (2004) Ensembles-based predictions of climate changes and their impacts (ENSEMBLES). EOS Trans Am Geophys Union 85:566
Holden J, Shotbolt L, Bonn A, Burt TP and others (2007) Environmental change in moorland landscapes. Earth Sci Rev $82: 75-100$

> Holdridge LR (1959) Simple method for determining potential evapotranspiration from temperature data. Science 130:572

> Hossell JE, Riding AE, Brown I (2003) The creation and characterisation of a bioclimatic classification for Britain and Ireland. J Nat Conserv 11:5-13

Hulme M, Jenkins GL, Lu X, Turnpenny JR and others (2002) Climate change scenarios for the United Kingdom: the UKCIP02 scientific report. Tyndall Centre for Climate Change Research, School of Environmental Sciences, University of East Anglia, Norwich

Kay AL, Davies HN (2008) Calculating potential evaporation from climate model data: a source of uncertainty for hydrological climate change impacts. J Hydrol 358: 221-239

Kilsby CG, Jones PD, Burton A, Ford AC and others (2007) A daily weather generator for use in climate change studies. Environ Model Softw 22:1705-1719

Koppen W (1900) Versuch einer Klassifikation der Klimate, vorzugsweise nach ihren Beziehungen zur Pflanzenwelt. Geogr Z 6:593-611; 657-679

Leighton DK (1997) Mynydd Du and Fforest Fawr: the evolution of an upland landscape in south Wales. Royal Commission, Aberystwyth

> Malby AR, Whyatt JA, Timmis RJ, Wilby RL, Orr HG (2007) Long-term variations in orographic rainfall: analysis and implications for upland catchments. Hydrol Sci J 52: 276-291

Maltby E (2010) Effects of climate change on the societal benefits of UK upland peat ecosystems: an ecosystem approach. Clim Res 45:249-259

Mather JR (1974) Climatology: fundamentals and applications. McGraw-Hill, New York, NY

Mather JR (1978) The climatic water budget in environmental analysis. Lexington Books, Toronto, ON

Murphy J, Sexton D, Jenkins G, Boorman P and others (2009) UK climate projections science report: climate change projections. Met Office Hadley Centre, Exeter

Nakicenovic N, Alcamo J, Davis G, de Vries B and others (2000) Special report on emissions scenarios: a special report of Working Group III of the Intergovernmental Panel on Climate Change. Cambridge University Press, Cambridge

Orr HG, Wilby RL, Hedger MM, Brown I (2008) Climate change in the uplands: a UK perspective on safeguarding regulatory ecosystem services. Clim Res 37:77-98

Peel MC, Finlayson BL, McMahon TA (2007) Updated world map of the Köppen-Geiger climate classification. Hydrol Earth Syst Sci 11:1633-1644

Perry M, Hollis D (2005) The generation of monthly gridded datasets for a range of climatic variables over the UK. Int J Climatol 25:1041-1054

> Prentice IC, Cramer W, Harrison SP, Leemans R, Monserud RA, Solomon AM (1992) A global biome model based on plant physiology and dominance, soil properties and climate. J Biogeogr 19:117-134

R Core Development Team (2008) R: a language and environmnet for statistical computing. R Foundation for Statistical Computing, Vienna

Ratcliffe D (1977) A nature conservation review: the selection of biological sites of national importance to nature conservation in Britain. Published on behalf of the Nature Conservancy Council and the Natural Environment Research Council, Cambridge University Press, Cambridge

Ratcliffe DA, Thompson DBA (1988) The British uplands: their 
ecological character and international significance. In: Usher MB, Thompson DBA (eds) Ecological change in the uplands. Blackwell Scientific Publications, Oxford

Sarkar D (2008) Lattice: multivariate data visualization with R. Springer, New York, NY

Smart SM, Henrys PA, Scott WA, Hall JR and others (2010) Impacts of pollution and climate change on ombrotrophic Sphagnum species in the UK: analysis of uncertainties in two empirical niche models. Clim Res 45:163-177

Smith J, Gottschalk P, Bellarby J, Chapman S and others (2010) Estimating changes in Scottish soil carbon stocks using ECOSSE. I. Model description and uncertainties. Clim Res 45:179-192

Thompson DBA, Brown A (1992) Biodiversity in montane Britain: habitat variation, vegetation diversity and some objectives for conservation. Biodivers Conserv 1:179-208

Submitted: March 11, 2010; Accepted: August 17, 2010
Thornthwaite CW (1948) An approach toward a rational classification of climate. Geogr Rev 38:55-94

Thornthwaite CW, Mather JR (1955) The water balance. Publ Climatol 8:1-104

Whitehead PG, Wilby RL, Battarbee RW, Kernan M, Wade AJ (2009) A review of the potential impacts of climate change on surface water quality. Hydrol Sc J 54:101-123

Wieder RK, Vitt DH (2006) Boreal peatland ecosystems. Springer, Berlin

Willmott CJ, Feddema JJ (1992) A more rational climatic moisture index. Prof Geogr 44:84-88

Willows RI, Connell RK (eds) (2003) Climate adaptation: risk, uncertainty and decision-making. UKCIP, Oxford

Worrall F, Evans MG, Bonn A, Reed MS, Chapman D, Holden J (2009) Can carbon offsetting pay for upland ecological restoration? Sci Total Environ 408:26-36

Proofs received from author(s): December 5, 2010 